\title{
Hulefâ ve Ulemâ Arasında Bir Rekabet ya da İş Birliği Alanı Olarak Savaş İdaresi (2-3/8-9. Yüzyıllar)
}

\author{
Nagihan Doğan*
}

\begin{abstract}
$\ddot{\mathbf{O} z}$
İslam tarihinin ilk yüzyılları üzerine yapılan bazı çalışmalarda, savaşın (cihâd) ilan ve idare yetkisi üzerine halife ve din âlimleri arasında rekabet yaşandığı, zühtçülükleri nedeniyle sınırlara cihat yapmak üzere giden din âlimleri ve onların emrindeki gönüllü din savaşçlarının devletle hiçbir münasebetlerinin olmadığı ve bu gerilimin savaş liderliği ve hatta dinî otoritenin halifeden hadis ilmiyle de ilgilenen bu zâhit-savaşçlara geçmesiyle sonuçlandığı iddia edilmektedir. Bu çalışmada, tarihsel verilerin böyle bir varsayımda bulunmak için yeterli olmadığı savunulmakta, iki taraf arasında savaşın ilan ve idaresi konusunda bir anlaşmazlık yaşanmadığı, aksine din âlimlerinin cihat doktrininde siyasi konjonktürü, yani aslında devletin ihtiyaçlarını dikkate alarak belirli revizyonlar yaptıkları ileri sürülmektedir.
\end{abstract}

Anahtar Kelimeler: Cihat, Halife, Hilafet, Ulema, Emevi, Abbasi, İslam Siyaset Düşüncesi

\section{The Conduct of War as a Rivalry or Cooperation Field Between Khulafā and 'Ulāma ( $2^{\text {nd }}-3^{\text {rd }} / 8^{\text {th }}-9^{\text {th }}$ Centuries $)$}

\begin{abstract}
In some studies on the first centuries of the history of Islam, it is claimed that there was a disagreement between the caliph and Islamic scholars ('ulam $\bar{a})$ over the declaration and conduct of the war (jih $\bar{a} d)$, that the Islamic scholars who swarmed to the borders for jihād because of their asceticism and the volunteer warriors for the faith under their command had no relation with the caliphate, that this tension resulted in the passing of the leadership of war and even religious authority from the caliphs to these ascetic-warriors who were also hadith scholars. In this study, it is argued that historical data are not sufficient to make such an assumption, that there is no dispute

* Dr. Öğr. Üyesi, Hacettepe Üniversitesi, Edebiyat Fakültesi, Tarih Bölümü, Ankara/TÜRKIYE, nagihan@hacettepe.edu.tr ORCID: 0000-0002-8769-2489

DOI: $10.37879 /$ belleten.2021.819

Makale Gönderim Tarihi: 03.11.2020 - Makale Kabul Tarihi: 08.02.2021
\end{abstract}

Belleten, Aralık 2021, Cilt: 85/Sayı: 304; 819-848 
between the two sides about the declaration and conduct of war, but on the contrary, Islamic scholars made certain revisions in the doctrine of jihād, taking into account the political conjuncture, in other words, the needs of the state.

Keywords: Jihād, Caliph, Caliphate, 'Ulamā, Umayyad, 'Abbāsid, Islamic Political Thought

\section{Giriş}

İslam siyaset düşüncesine ilgi duyan her araştırmacı I. M. Lapidus'un din ve devlet arasındaki ilişkiye dair tezini ${ }^{1}$ iyi bilir. Lapidus, Orta Çă İslam toplumunda din ve siyasetin farklı otorite alanları oluşturduğunu ve bunların biri din âlimleri diğeri halifeler olmak üzere farklı liderler tarafindan temsil edildiklerini ileri sürmüştür. Başta D. Tor ve M. Bonner olmak üzere bazı araştırmacılar ulemânın savaş/cihat alanındaki görünürlük ve etkinliği fikrinden yola çıkarak halifenin cihadın ilan ve idaresinde rakipsiz olmadığını savunmuş ve Lapidus’un varsayımını desteklemişlerdir. Onlara göre hilafetin uzun süredir dinî meşruiyetten yoksun olduğunu düşünen, bu nedenle onun temsilcilerine muhalif bir tutum içinde olan hadis ulemâsının askerî kanadı ve onların emrindeki gönüllü din savaşçıları (مطوعة عutavvi`a veya منطو عة-mutatavvi'a) geç Emevi veya erken Abbasi döneminden itibaren siyasî otoritelerden bağımsız şekilde savaşmaya başlamışlar, böylece Peygamber döneminden itibaren devletin ana fonksiyonlarından birini oluşturan cihat ve hatta dinî otorite hükûmetin tekelinden çıkmıştır ${ }^{2}$.

Bu çalışma, yukarıdaki varsayımın aksine bir ibadet ya da züht pratiği olarak her Müslümana açık olmakla birlikte fetih ve sınırları koruma konusundaki liderliğin halifeye ait olduğunu ve bu durumun din âlimleri tarafindan sorgulandığına dair

1 Ira M. Lapidus, "The Separation of State and Religion in the Development of Early Islamic Society", International Fournal of Middle East Studies, 6/4, (1975), s. 363-385.

2 Deborah Tor, Violent Order: Religious Warfare, Chivalry, and the Ayyar Phenomenon in the Medieval Islamic World, Istanbuler Texte und Studien der Deutschen Morgenländischen Gesellschaft, Ergon Verlag, Würzburg 2007, özl. s. 34-83; Michael Bonner, Fihad in Islamic History, Princeton University Press, 2006, s. 97-117, 127-131. Ayrica bk. A. Asa Eger, The Islamic-Byzantine Frontier: Interaction and Exchange Among Muslim and Christian Communities, I. B. Tauris, London\&New York, 2015, s. 238; Christian C. Sahner, "The Monasticism of My Community is Jihad: A Debate on Asceticism, Sex and Warfare in Early Islam", Arabica, 64 (2017), s. 176-177; Saud S. Al-Zaid, "The Apocalyptic Frontier: Tarsus and the End of the World", MEHAT Workshop and Conference, 19th Annual Meeting-2004; Harry S. Neale, Fihad in Premodern Sufi Writings, Palgrave Macmillan, New York 2017, s. 96. 


\section{Olarak Savaş İdaresi}

inandırıcı delillerin bulunmadığını savunmaktadır. Amaç, cihadın İslam fikhınca bir devlet mesuliyeti olarak tasarlandığını, halifelerin dinî otoritenin bir kısmını ulemâ ile paylaşmak zorunda kalmakla birlikte cihat söz konusu olduğunda bu alanda -dinî değil- siyasi otoriteleri zarar görmediği sürece bir tekel oluşturduklarını, ulemânın bu konuda devlete meydan okumadığı gibi cihat doktrinini devletin ihtiyaç ve beklentilerine uygun şekilde revize ettiğini, dolayısıyla cihadın halifeler ve din âlimleri arasında hiçbir zaman bir rekabet alanı oluşturmadığını göstermektir.

Çalışmanın çıkış noktası, geç Emevi ve erken Abbasi döneminden başlamak üzere halifelerin cihat konusunda genel olarak ulemâ, özel olarak zahit-savaşçllar ve onların emrinde olduğu söylenen gönüllülerle dinsel otoritelerinin sarsılmasıyla sonuçlanan bir çatışma yaşadıkları şeklindeki varsayımdır. 3/9. yüzyıldan itibaren İslam dünyasının farklı bölgelerinde ortaya çıan yerel Müslüman hükümdarların ulemâ ve gönüllülerle benzer bir çatışma yaşayıp yaşamadıkları başka bir araştırmanın konusu olup ayrıca incelemeye değerdir. Konuyla ilgili verilerin dağınık olması, araştırmayı kısa bir zaman dilimiyle sınırlandırmaya izin vermemektedir. Ancak farklı dönemlere ait bu verilerin kendi içinde tutarlılık gösterdiği görülmüştür. Bu sebeple çalışmada daha önceki ve daha sonraki dönemlere kısa atıflar yapılmakla birlikte 2-3/8-9. yüzyıllar arası gibi uzun bir tarihsel süreç ele alınmış, daha doğrusu böyle bir mecburiyet doğmuştur.

\section{Rekabet?: Ulemâ ve Mücahitlik}

Klasik İslam yazını ve fikhına göre halifenin en önemli görevi, Müslümanların öteki dünyaya en iyi şekilde hazırlanmaları için gerekli koşulları sağlamaktı; bunun için halife bir yandan iç düzeni tehdit eden "bozguncular ve fitnecilerle" mücadele ederken, diğer yandan dış tehdit oluşturan "kâfirlere" karşı Müslümanların can ve mal güvenliğini korumalı ve İslam'ın dinî-siyasi hakimiyetini olabilecek en geniş sinırlara ulaştırmalıydı. Arapça cihâd terimiyle ifade edilen bu sorumluluk, iç politikada aynı zamanda dinî bir meydan okuma olarak da görülen her türlü siyasi başkaldırının üstesinden gelmeyi, dış politikada ise orduların sevk ve organizasyonunu kolaylaştıran mükemmel bir ideolojik söylemdi.

Hz. Muhammed'in dinî ve siyasi otoriteyi aynı anda kendi şahsında birleştirmesi daha sonraki yöneticiler için örnek oluşturmuş ve halifeler de kapsam ve mahiyeti değişmekle birlikte çift yönlü bir otorite iddiasında bulunmuşlardı. Peygamber vefat ettiğinde dinî otoriteyi sahiplenecek kilise benzeri bir kurumun olmaması durumu kolaylaştırdı. Ancak zamanla kendilerini Allah'ın iradesini keşfetmeye ve dinî 
çalışmalar yapmaya adayan, helal-haram konusunda görüş bildirmeye ehliyetli olduklarından yaygın kabul ve saygı gören insanların ulemâ adı verilen bir sınıf oluşturacak şekilde çoğalması, dinsel otoritenin tamamen değilse bile bir ölçüde halifelerin ellerinden kaymasıyla sonuçlandı. Bununla birlikte dinî otoritenin sahibinin kim olduğu konusunda büyük bir ihtilaf yaşanmadı. Tersine bu konuda açık bir iş birliği vardı: Din âlimleri Allah'ın iradesini somut kurallara dönüştürecek, halifeler de bu kuralları tatbik edeceklerdi. Halifenin dinsel bir doktrin belirleme ve dayatma hakkı yoktu. Ama konu eğer cihadın idaresiyse, bu alandaki otorite kesinlikle halifeye aitti. Ulemânın görevi aktif silahlı mücadeleye katılmaktan çok insanların savaşa katılmalarını kolaylaştırmak ve savaşın meşru olduğunu göstermeye yarayan hukukî düzenlemeler yapmaktı. Nitekim fikıh kitapları ve büyük hadis koleksiyonlarında genellikle Kitâbu'l-Cihhâd (veya Kitâbu's-Siyer) adı verilen bir bölüme yer verildi. Din âlimleri, Peygamber'e atfedilen bir dizi hadis ve cihadın faziletlerinden bahseden haberlerle Müslümanları gönüllü asker olarak bilhassa Suriye suğûrundaki şehir ve kalelere yerleşmeye teşvik ettiler.

Ulemâ arasında cihadı teşvik etmekle kalmayıp aktif olarak savaşa katılan isimler de vardı. Bu kişiler, sınırın karşı tarafindaki Hristiyan zahitlere benzer şekilde orduya kaydolmadan hayatlarının bir dönemini mukaddes addettikleri bu görevin ifası için sınırlarda geçirdiler. Ancak savaş tercübesi edinmek isteyen din âlimlerinin sayısı oldukça sınırlı olup bunların biyografilerinde suğûrda geniş kitleleri örgütleyen ve yöneten bir cihat hareketi başlattıklarına dair ipuçları yoktur. İbn Sa'd (ö. 230/845) devasa biyografik eseri Tabakâtii'l-Kübrẩda "suğûr ve avâsımda bulunanlar" başlığı altında sadece on dokuz isim vermiş, üstelik bunlardan ancak birkaçını savaşçllık özelliği ile anmıştır³. Benzer bir durum, İbnü'l-Cevzî’nin (ö. 597/1201) Ebû Nu'aym el-İsbehânî’ye (ö. 430/1038) ait Hilyetï'l-Evliyẩyı esas alarak kaleme aldığ̣ Sifatü's-Safve için de geçerlidir. O burada "avâsım ve suğûr halkından seçkin kişiler" başlı̆̆ı altında on yedi isim zikretmiş, bunlardan sadece dört tanesini gâzî olarak vasıflandırmıştır ${ }^{4}$. Hagiografik literatürün bu iki önemli örneğinde bile cihadın yaygın bir züht pratiği olarak görünmemesi kayda değerdir.

Kaynaklarda 3/9. yüzyılın ikinci yarısından itibaren (ama çoğu 4/10. yüzyılda olmak üzere) gönüllü askerlere reislik yapan bazı din âlimlerinin isimlere rast-

3 İbn Sa‘d, Tabakâtü'l-Kübrâ, C VII, Dârü'l-Kütübi'l-'İlmiyye, Beyrut 1997, s. 339-341.

4 İbnü'l-Cevzî, Sifâtü’s-Safve, G II, Dârü'l-Hadîs, Kahire 2000, s. 404-422. Üstelik bu listedeki Ahmed b. 'Âsım el-Antâkî'ye, en faziletli cihadın nefse ve en tehlikeli düşman olan şeytana karşı yapılan cihat olduğu düşüncesi atfedilir: C II, s. 418. Benzer bir görüş, İbrahim b. Edhem’e aittir: "En zor cihat heva ile mücadele etmektiv": age., C VI, s. 256. 
lamak mümkünse de bunların sayısının da az olduğu anlaşlıyor. Zehebî’nin (ö. 748/1348) Târîhu'l-İslâm'nda bu özelliğe sahip olarak ismi geçen din âlimi sayısı son derece azdır ${ }^{5}$. Aynı müellifin Siyerï A 'lâmi’n-Nübelâ isimli tabakât kitabında da benzer bir durum söz konusudur. Eserde gönüllülere reislik yaptığı söylenen iki isim tespit edilebilmiştir ${ }^{6}$. Sem ânî de (ö. 562/1166) kabile, mezhep, ülke, meslek gibi aidiyetler üzerinden kaleme aldığı el-Ensâb'da meşâyihü'l-guzât'tan (gazilerin şeyhleri) olduğunu söylediği sadece birkaç isme yer vermiştir ${ }^{7}$. Öte yandan eserde gâzî nisbesi ile anılanların sayısı sadece on birdir ${ }^{8}$. Üstelik bu isimlerin yönetici ve onlara bağlı düzenli ordularla ilişkilerine dair bir bahis bulunmaz.

Tor, Bonner ve onları takip eden araştırmacıların geç Emevi ve erken Abbasi döneminden itibaren din âlimlerinin suğûra adeta akın edip gönüllü din savaşçılarını kendi liderlikleri altında topladıklarını ve halifeye meydan okuduklarını iddia ederken verdikleri örneklerde bilhassa dört isim geçiyor: Abdurrahman b. 'Amr el-Evzâî̀ (ö. 157/774), İbrahim b. Edhem (ö. 161/778?), Abdullah b. el-Mübârek (ö. 181/797) ve Ebû İshâk el-Fezârî (ö. 188/804?). Burada her şeyden önce hükûmet tarafindan organize edilen askerî seferlere bazen din âlimlerinin de eşlik ettikleri ${ }^{9}$, hatta bunlardan bazılarının ordu komutanlığı yaptıkları ${ }^{10}$, ayrıca kass (ç. kussâs) mansıbıyla orduda vaizlik yapan ve askerleri cihada teşvik eden din âlimlerinin bulunduğunu ${ }^{11}$ hatırlamak gerekir. Dolayisiyla daha bu noktada suğûrrda cihat konusunda bir tarafta halife diğger tarafta din âlimlerinin olduğu bir bölünme yaşandığını hayal etmek güçleşir. Öte yandan kaynaklar savaş idaresinde fikhî

5 Zehebî, Târîhu'l-İslâm ve Vefayâtü'l-Meşâhir ve'l-A 'lâm, Dârü'l-Garbi'l-İslâmî, Beyrut 2003, G V, s. 993; C VI, s. 447, 453; C VII, s. 865; C VIII, s. 394, 418.

6 Zehebî, Siyerü A'lâmi’n-Nübelâ, C III, Beytü’l-Efkâri’d-Düveliyye, Lübnan 2004, s. 3308 ve 4201.

7 Sem‘ânî, el-Ensâb, Meclisü Dâ'ireti'l-Me‘ârifi'l-'Osmâniyye, Haydarâbâd 1977, G V, s. 33; C VI, s. 49; C X, s. 5.

8 Sem'ânî, age., C X, s. 4-6.

9 İbnü'l-Esîr, el-Kâmil fît-Târîh, Beytü'l-Efkâri'd-Düveliyye, by. ve bt. yok, s. 649; Taberî, Târîh (Târîhu'l-Ümem ve'l-Mülûk), Beytü'l-Efkâri'd-Düveliyye, by. ve bt. yok, s. 1817; Kindî, Kitâbu'l-Vulât ve Kitâbu'l-Kudât, Dârü'l-Kütübi'l-'Ilmiyye, Beyrut 2003, s. 259; Belâzürî, el-Büldân ve Fütûhuhâ ve Ahkâmuhâ, Dârü'l-Fikr, Beyrut 1992 s. 199; İbn Hacer el-Askalânî, Ref'ul-Isr 'an Kudâti Misr, Mektebetü'l-Hâncî, Kahire 1988, s. 461, 463; John Kelsay, "Al-Shaybani and the Islamic Law of War", fournal of Military Ethics, II/ 1 (2003), s. 65.

10 Zehebî, Siyer, C I, s. 1076-1077. Ayrıca bk. Lyall R. Armstrong, The Qusșās of Early Islam, Brill, Leiden 2017, s. 261, 290.

11 Sem'ânî, age., C X, s. 303; Kindî, age., s. 220; Armstrong, age., s. 49-63; Khalil Athamina, "Al-Qasas: Its Emergence, Religious Origin and Its Socio-Political Impact on Early Muslim Society", Studia Islamica, LXXVI (1992), s. 53-74. 
kurallara riayet konusunda yukarıda geçen dört isim ve başka din âlimlerinin memnuniyetsizliklerini ifade eden kayıtlara yer vermezler. Bu, fikhın bu alandaki tatbikinde ciddi sorunlar yaşanmadığını gösterir ki halife ya da valiler çok erken bir dönemden itibaren kâdî̀-cü̈nd (sonradan kazasker) mansıbıyla, askerler tarafindan işlenen suçlar, esirlerin durumu, ganimet paylaşımı, ölen askerlerin mirası, düşman malına zarar vermenin sınırları gibi fikhî konular hakkında fetva veren ${ }^{12}$ görevliler tayin etmişlerdir.

Orta Çă̆ İslam dünyasında savaşçılık din âliminin karakteristik özelliklerinden biri değildi. Ama asıl ilginç olan şey, cihada tüm din âlimlerinin aynı önemi atfetmemiş olmalarıdır'². İbn Rüşd'e (ö. 595/1198) bakılırsa cihadın farz-ı kifâye olmak şöyle dursun tatavou (nafile ibadet) olduğunu düşünen âlimler vard ${ }^{14}$. Gerçekten de kaynaklarda İbn Rüşd'ü doğrulayan kayıtlara rastlamak mümkündür. Örneğin Kûfeli fakih Hammâd b. Ebî Süleyman'a (ö. 120/738) "cihada itiraz etmek şeytanın dürtmesidir" sözleri atfedilir ${ }^{15}$ ve o gerçekten böyle söylemişse buradan o dönemde cihadın dinî bir yükümlülük olarak dayatılmasına itiraz edenler olduğu sonucu çlkar. Nitekim 2/8. yüzyllın meşhur âlimlerinden Süfyân es-Sevrî̀nin (ö. 161/778) bazı Kur'ân ayetlerini (2:191, 9:36) delil göstererek savaşı başlatan taraf olmadıkça müşriklerle savaşmanın farz olmadığını savunduğu söylenir ${ }^{16}$. Onun cihatla ilgili tutumunu anlamaya yardımcı olacak başka bir kayıt daha bulunur. Buna göre dinsel fazilet arayışında olup kendine ikâmet edecek bir belde arayan Süfyân, çevresindekilerin Şam ya da Horasan'a yerleşme önerilerini ciddiye almamışıı'ı ${ }^{17}$. Eğer gerçekten böyle olmuşsa bu, cihadın en aktif sürdürüldüğü bu beldelerin Süfyân

12 Bu konuda bk. Nizâr Azîz Habîb Muhammed, "Kâdîll-Cünd", Mecelletï Ebhâsi'l-Basra, XXXVIII/1 (2013), s. 120-141. Örnekler için bk. Taberî, age., s. 1620; Sem‘ânî, age., C V, s. 3334; İbn Sa'd, age., C V, s. 493; Kindî, age., s. 260.

13 İslam toplumunda savaş ve din arasında çok yakınmış gibi görünen ilişkiye rağmen Kur'ân ve sünnet, bazı Müslüman tarihçi ve fikıhçıların savaşa atfettikleri koşulsuz dinsel bağlayıcılığı açıklamaz, zira savaşın gerekliliği ve kaçınılmazlığı için belirli şartlar aranmıştır. Bu konuda bk. Albrecht Noth, Müslümanlikta ve Hiristiyanlıkta Kutsal Savaş ve Mücadele, çev. İhsan Çatay, Özne Yay., İstanbul 1999, s. 18, 30, 42; Fred M. Donner, "Fight for God - But Do So with Kindness: Reflections on War, Peace and Communal Identity in Early Islam", War and Peace in the Ancient World, ed. Kurt A. Raaflaub, Blackwell Publishing, 2007, s. 299-301. İbn Rüșd, Bidâyetii'l-Müctehid ve Nihâyetiu'l-Muktesıd, Mektebetü ve Matba'atü Mustafa el-Bâbî el-Halebî, Kahire 1975, s. 380-381. İsbehânî, Hilyetü'l-Evliyâ' ve Tabakâtü'l-Esfiyâ', C VI, Dârü'l-Hadîs, Kahire 2009, s. 288. Şeybânî ve Serahsî, Şerhu Kitâbi’s-Siyeri’l-Kebîr, C I, Dârü’l-Kütübi'l-'İlmiyye, Beyrut 1997, s. 131. 


\section{Olarak Savaş İdaresi}

için hiçbir cazibe taşımadığı anlamına gelir. Aynı şey başkaları için de geçerlidir. Bilhassa sinırlara ve savaş bölgelerine uzak olan Mekke ve Medineli âlimlerin, cihadın zorunlu bir dinsel eylem olduğunu söylemeye istekli olmadıkları anlaşılıyor. Doğru olsun ya da olmasın şu kayıtlar o dönemde cihadın daimi bir dinsel yükümlülük olarak kabul edilmesine karşı çıkan insanların olduğunu göstermesi bakımından çok anlamlıdır: İbn Cüreyc (ö. 150/767) Mekkeli fakih 'Atâ b. Ebî Rebâh’a (ö. 114/732) cihadın her Müslümana vacip olup olmadığını sorar. O ve yanında bulunan Mâlik b. Dinâr (ö. 131/748'den önce) "bilmiyoruz" şeklinde cevap verirler $^{18}$. İbn Kuteybe'nin (ö. 276/889) 'Uyûnü'l-Ahbâr'ında gazada 1srar etmenin sakıncalı olabileceğini ima eden ilgi çekici bir anlatı bulunuyor. Buna göre Mekke halkı Fudayl'a gelip kuraklıktan şikâyet eder. Fudayl onlara bunun Allah'ın takdiri olduğunu ve buna razı gelmek gerektiğini söyleyip ibret olsun diye Allah’tan gaza için Tarsus'a gitmeyi dileyen, duası kabul edilince esir düşüp Hıristiyan olan bir adamın hikâyesini hatırlatır ${ }^{19}$. Burada adı geçen Fudayl muhtemelen Mekke'de mücâvir olarak yaşayan ve yakın dostu Abdullah b. el-Mübârek ile cihadın vacipliği konusunda anlaşamadığı söylenen Fudayl b. 'İyâz’dır (ö. 187/ 803). Medineli fakih Mâlik b. Enes'in de (ö. 179/795) cihada karşı duruşunun mesafeli olduğuna dair işaretler var. Örneğin ondan el-Muvattâ’yı dinleyen Şeybânî (ö. 189/805) tarafindan yapılan derlemede, Leysî̀ye (ö. 234/849) ait diğger derlemede yer alan cihat faslının olmadığı göze çarpıyor. Şeybânî’nin kasıtlı olarak bu bölümü kitaptan çıkarması Leysî’nin olmayan bu bölümü kitaba eklemiş olmasından daha az olası. Zira burada Leysî’nin Kurtubalı olmasının anlamı üzerine düşünmek gerekiyor ${ }^{20}$. Öte yandan Mâlik b. Enes’in cihat konusundaki tutumuyla ilgili şöyle bir rivayet bulunuyor: Bir âbid Mâlik'i inzivaya ve amele teşvik eder ve Mâlik’ten şu cevabı alır: "Allah amelleri tıpkı nzıklarn paylaştırdiğ gibi paylaştırmıştır. Pek çok kişiye [bol] namaz kılmayn ilham etmis, ama [bol] oruç tutmayn etmemiştir. Kimisine [bol] sadaka vermeyi ... kimisine de cihadr ilham etmiştir. Ilim yaymak en hayırl amellerdendir. Ben Allah'ın bunu bana ilham etmesinden razıyım ${ }^{21}$. Mekkeli fikıh otoritelerinden biri kabul edilen Abdullah b. el-Abbas'a (ö. 68/687) ise şu sözler atfediliyor: "[Kendisine cihat hakkında soru soran kişiye hitaben] sana en iyi cihadın ne olduğunu söyleyeyim mi? Mescit inşa edip içinde Kur'ân, fikı ve sünnet ögrenmek ${ }^{22}$." Benzer bir hikâyede cihadın dinsel bir mecburiyet

18 San'ânî, el-Musannef, C V, el-Meclisü'l-'Illmî, Beyrut 1972, s. 171.

19 İbn Kuteybe, Kitâbu 'Uyûni'l-Ahbâr, C II, Dârü'l-Kitâbi'l-'Arabî, Beyrut 2002, s. 731.

20 J. Chabbi, "Ribāṭ", Encyclopaedia of Islam, C VIII, Second Edition, s. 495-496.

21 Zehebî, Siyer, C III, s. 3161-3162.

22 İbn Ebî Ya'la, Tabakâtü’l-Hanâbile, C II, Dârü'l-Kütübi’l'İlmiyye, Beyrut 1997, s. 192. 
olmadığını iddia eden kişi Abdullah b. Ömer b. el-Hattâb'dır (ö. 73/693). Hikâyeye göre Abdullah'ın yanına bir adam gelir ve ona neden cihat yapmadığını sorar. Abdullah'ın verdiği cevap şöyledir: "İslam dört temel üzerine bina edilmiştir: Namaz kllmak, zekât vermek, oruç tutmak ve güç yetiyorsa hacca gitmek. Cihat ve sadaka [ise sadece] güzel amellerdendi ${ }^{23}$."

Belli ki fakihler, cihadın dinsel bağlayıcılığı konusunda uzlaşmaya varmış değillerdi. Bu düşünce farklılı̆̆ı, bazen iki dinsel seyahat türü, yani hac ve cihat arasında kıyaslama yapan bir efdaliyet tartısması biçiminde tezahür etti. Bir tarafta murâbatayı (sinırda nöbet bekleme), hac ya da mücâvere (kutsiyetinden dolayı Mekke veya Medine'de yaşama) ile eşdeğer ya da ondan efdal bir ibadet olarak değerlendiren, Müslümanlardan nasıl hac için Mekke'ye gitmeleri gerekiyorsa murâbata için de her yll düzenli olarak suğûra gitmelerini isteyenler ve bu düşünceleri empoze eden hadis ve haberler vardı ${ }^{24}$. İbn Şebbe'ye (ö. 262/876) bakılırsa, Osman b. Affân cihadın hacdan efdal olduğunu düşünmekteydi, ama sonra bu fikrinden vazgeçip tövbe etmiş ve kendisinden hac izni isteyenlere izin vermişti ${ }^{25}$. Aynı düşüncenin atfedildiği başka bir halife es-Seffâh oldu. Belâzürî (ö. 279/892-93) tarafindan kayda geçirilen bir rivayete göre es-Seffâh, Horasan valisi Ebû Müslim'in hacca gitme talebini "cihat hacdan efdaldir" diyerek reddetmişti ${ }^{26}$. Uydurma oldukları varsayılsa bile her iki rivayet de en azından 3/9. yüzyllda bu iki dinsel seyahat türünün hangisinin daha üstün olduğuyla ilgili bir fikir ayrllğğ olduğunu gösteriyor ${ }^{27}$. Şu meşhur hadisin, cihatla kiyaslandığında mücâverenin daha az önemli bir dinsel eylem olduğu mesajını verdiği çok açıktır: "Fetihten sonra hicret yoktur. Cihat ve cihada niyet

23 San'ânî, age., C V, 173. Cihada katılıp katılmamanın bir tercih meselesi olduğunun Hz. Muhammed tarafindan da tasdik edildiğine işaret eden bir hadis için bk. Buhârî, es-Sahîh, C III, Dârü'l-Hüdâ, Cezayir 1992, s. 1028.

24 Buhârî, age., C II, s. 553; Nesâî, Kitâbu's-Süneni'l-Kübrâ, C. II, Dârü'l-Kütübi'l-‘ílmiyye, Beyrut 1991, s. 320; San'anî, age., C V, s. 260; İbn Nehhâs, Meşâri'u'l-Eş̧âk ilâ Mesâri i'i'l-'Uş̧âk ve Müsîrü'l-Garâm ilâ Dâri's-Selâm (fi'l-Cihâd ve Fezâ'ilihi), Dârü'l-Beşâ’iri'l-İslâmiyye, Beyrut 1990, s. 134136, 204-209, 384-390.

25 İbn Şebbe, Târîhu'l-Medîneti'l-Münevvere, C III, Cidde 1399, s. 1129.

26 Belâzürî, Kitâbu Cümel min Ensâbi'l-Eşrâf, C IV, Dârü'l-Fikr, Beyrut 1996, s. 244.

27 Ömer b. el-Hattâb’a atfedilen ve Mekke halkının "kat kat sevap kazanmak için" cihada teşvik edildiği bir hutbede cihadın mı yoksa mücâverenin mi daha üstün olduğu ile ilgili görüş̧ ayrılığının izlerini görmek mümkündür. Rivayet, Şeybânî’nin es-Siyerï'l-Kebîr'indeki “Ribâtın Fazileti” isimli bölümde geçer. Sonradan Serahsî’nin yaptığı şerhe göre Hz. Ömer’in buradaki maksadı, Mekkelilerin Kâbe'nin komşusu olmalarına güvenerek cihat ve sevabından geri kalmalarına mâni olmaktır, zira o cihadın sevabının mücâverenin sevabından daha fazla olduğuna inanan biridir: age., C I, s. 10-11. 


\section{Olarak Savaş İdaresi}

vardır. Öyleyse cihada çăgrıldığınızda icabet ediniz ${ }^{28}$." Burada kastedilen şey, Mekke’nin fethinden sonra Medine’ye hicret etmeye gerek kalmadığı, Müslümanların göç adresinin bundan böyle -cihat yapmak üzere- garnizon şehirler olduğudur. Nitekim Ebû Dâvûd (ö. 275/889) bu hadisten hemen sonra peş peşe Hz. Muhammed'in Müslümanlara Şam'a gitmelerini tavsiye ettiği iki hadis verir ${ }^{29}$. Aynı mesajı veren başka bir hadiste bir adam Peygamber'e gelip insanlardan hicretin bittiğini duyduğunu söyler. Bunun üzerine Peygamber, "kâfirlerle savaşıldiğg müddetçe hicret bitmez" der $^{30}$. Burada hicrete atfedilen anlam, sadece ve özellikle Medine’ye değil kâfirlerle savaşın gerekli olduğu yere göçtür.

Abdullah b. el-Mübârek kaynaklarda cihadı mücâvereye üstün tutan düşüncenin en iyi temsilcisi olarak gösterilir. O gerçekten de Kitâbu'l-Cihâd isimli çalışmasında cihadın hâcdan (özellikle de ikinci hacdan) daha efdal olduğunu söyleyen birkaç habere yer vermiştir ${ }^{31}$. Öte yandan Abdullah'ın kendini ibadete vermek için Mekke'de uzlete çekilen Fudayl b. İyâz'a gönderdiği bir mektupta cihat dururken mücâvereyi tercih edenleri şu dizelerle eleştirdiği söylenir:

Ey Harameyn'in (Mekke ve Medine'nin) âbidi!

Ĕger bizleri [savaşırken] görseydin,

Anlardın ibadetle oyalandığını.

Yanaklarını gözyaşları ile ıslatan kimse!

[Bak] bizim boğazlarımız kanlarımızla ıslanıyor ${ }^{32}$.

Gihadı haccın önüne geçirenlerin karşısındaysa yukarıdaki şïrin muhatabı Fudayl b. İyâz örneğinde olduğu gibi hacca gidip Mekke'de ikâmet etmek varken cihat için sınıra gitmenin doğru olmadığını savunanlar vardı. Şu rivayet, mücâvereyi cihattan üstün tutan görüşe iyi bir örnek oluşturur: Bir adam, Abdullah b. Ömer b. el-Hattâb'a neden cihadı terk edip her yıl hacca gittiğini sorar. Abdullah, İslam'ın beş şartını hatırlatır ve bunlardan birinin hacca gitmek olduğunu söyler. Bunun

28 San'âni, age., C V, s. 309; Şeybânî ve Serahsî, age., s. 69; Buhârî, age., C III, s. 1025; Nesâî, age., C IV, s. 426; İbn Hazm, el-Muhallâ, İdâretü't-Tıbâ'ati'l-Münîriyye, Kahire 1349, C VII, s. 291.

29 Ebû Dâvûd, es-Sünen, C IV, Dârü'r-Risâleti'l-'Âlemiyye, Dımaşk 2009, s. 137-139. Kaynaklarda başta Şam olmak üzere cihat için gidilen yerlerin dârü'l-hicret, gidip savaşanların da mühâcir olarak isimlendirildiği bolca kayıt vardır. Buna dair uzun bir liste için bk. Patricia Crone, "The first-century concept of hiğra”, Arabica, 41 (1994), s. 356-363.

30 Nesâî, age., C IV, s. 427.

31 Abdullah b. el-Mübârek, Kitâbu'l-Gihâd, Dârü'l-Matbû‘âti'l-Hadîse, Cidde ty., s. 186-187.

32 Zehebî, Siyer, C II, s. 2476. 
üzerine adam ona cihatla ilgili birkaç ayet zikreder. Abdullah'ın her ayet için bir cevabı vardır. Adam en son Kur’ân'daki "fitne ortadan kalkıncaya kadar onlarla savaşın" (2:193) sözlerini hatırlatır. Abdullah, Peygamber'in hayatta olduğu dönemde bunun yapıldığını söyler ve İslam güçlendiği ve Müslümanların sayısı arttığı için artık cihada gerek kalmadığını ima eder ${ }^{33}$. Bu konuşma gerçekten yapılmış olsun ya da olmasın belli ki savaşmak için suğûra gitmenin, fikıh çalışmak ya da mücâvir olarak Mekke'ye gitmekten daha değerli olmadığını savunanlar vard ${ }^{34}$. Öyle ki yaygın manasıyla suğûrda nöbet beklemek [ve gerekiyorsa Allah yolunda savaşmak] anlamına gelen ribât için hem Kur'ân hem de hadislerde alternatif izahlar arandı. Bu bakış açısına göre gerçek ribât, nefsi dizginlemek ve Allah'a ibadette sebat göstermekti ${ }^{35}$. Başka deyişle ribât yapmak için suğûra gitmeye gerek yoktu. Haccı ya da mücâvereyi cihada üstün tutmamakla birlikte hacca gitmenin de bir tür cihat olduğunu ifade eden hadis ve haberler de ${ }^{36}$ aynı mesajı veriyordu: Müslümanın cihat yapmak için illa eline kılıç alıp savaşması gerekmez. Hac/mücâvere ile cihat taraftarları arasındaki efdaliyet tartışması aşağıda görüleceği üzere cihadın ilk kez Şâfîi (ö. 204/820) tarafindan farz-ı kifâye olarak tanımlanmasıyla ve yaygın kabul görmesiyle ilk grup lehine sonuçlandı. Suğûrda dinsel fazilet arayışında olan din âlimlerinin sayısının fazla olmamasının nedenini biraz da burada aramak gerekir.

Hem Tor hem de Bonner, gönüllü din savaşçılarını aynı ideolojiyle bir araya gelmiş, aynı dinsel yaşam tarzını benimseyen ve ortak amaçlar doğrultusunda hareket eden bir topluluk olarak betimler: Onlar zühtçü, hadisçi ve hükûmet muhalifidirler ${ }^{37}$. Tor, ayrıca son iki özellik arasında yakın bir ilişki olduğunu düşünür. Buna göre hadisçiliği ortaya çıkaran şey, din âlimlerinin imam, yani devlet başkanı konusunda yaşadıkları hayal kırıklığıdır, hadisçiler sünnet üzerine çalışmakla cemaatin rehberi olarak Hz. Muhammed'i meşruiyeti şüpheli olan halifenin yerine geçirmişlerdir. Ancak hulefâ ile ulemâ arasında cihadın idaresi konusunda bir çatışma yaşandığını varsaymak için her üç özellik ve bunlar arasında varolduğu iddia edilen ilişki birtakım sorunlar taşır.

Öncelikle gönüllü din savaşçlığı hareketinin kurucu isimleri olarak gösterilen din âlimlerinin bu işi devletten bağımsız, hele hele ona meydan okurcasına ifa ettik-

33 Zehebî, Siyer, C II, s. 2441; rivayetin farklı bir versiyonu için bk. San'anî, age., C V, s. 173.

34 Chabbi, age., s. 495-496.

35 İbn Manzûr, Lisânu'l-Arab, C VII, Dâru Sâdır, Beyrut 2010, s. 302-303.

36 San'anî, age., C V, s. 7, 174; Ezrakî, Ahbâru Mekke ve mâ Câe fîhâ mine'l-Âsâr, Mektebetü'l-Esedî, by. yok 2003, s. 492.

37 Tor, age., s. 44-45; Bonner, age., s. 101. 


\section{Olarak Savaş İdaresi}

lerini gösteren işaretler bulunmamaktadır. Tersine, örneğin Evzâ‘̂̂, halifenin izni olmadan dârü'l-harbe girmeye sıcak bakmayan biridir. Hatta o, imamin ondan izin almadan dârü'l-harbe gidip savaşan birini isterse cezalandırabileceği ve elde ettiği ganimetten ona pay vermeyebileceğini savunmuştur. Ona göre bu kişinin affedilip topladığı ganimetten pay alması tamamen halifeye bağlıdır ${ }^{38}$. Ebû İshâk elFezârî'nin Kitâbu's-Siyer isimli çalışması hocası Evzâ‘̂̂’nin izinden gittiğini gösteren işaretler taşır. Fezârî burada ne cihat ne de başka bir konu üzerinden halifenin dinsel otoritesini sorgulamıştır. Üstelik Evzâ‘î; Süfyân es-Sevrî ve başka fakihlerin bir kişinin imamın izni olmadan düşmana saldırmasından hoşlanmadıklarını kayda geçirmiş ${ }^{39}$, hatta bir yerde savaşta atını ve silahını kaybeden askerin ancak zaruret halinde imamdan izin almadan fey içinde bulunan binek ve silahları kullanabileceğini belirtmiştir ${ }^{40}$. Abdullah b. el-Mübârek'e gelince; onu gönüllü din savaşçılığ1 hareketinin lideri ve daha da önemlisi halifenin bu alandaki otoritesine meydan okuyan biri olarak görmek için ona atfedilen birtakım sözleri görmezden gelmek gerekir: "Zalim ya da adil her halifeyle birlikte cihat caizdir diyenler, kulıcla sultana karşı ayaklanmay tasvip etmeyenler ... hâricî (isyancı) olmaktan çıkarlar ${ }^{41}$." İbrahim b. Edhem bu dört isim içinde siyasetle en az meşgul olan kişidir. Hatta hakkındaki biyografik kayıtlarda onun memleketini terk edip Şam’a gelmesinin nedeni, savaşmak değil ilim tahsil etmek olarak gösterilir ${ }^{42}$.

İddia edilenin ${ }^{43}$ aksine bu kişilerin hükûmetle aralarına koydukları mesafe ve halife karşısındaki eleştirel duruşlarına dair rivayetler, iki taraf arasında cihadın idaresinde bir çatışma veya rekabet olduğu sonucunu doğurmaz. Zira bu tutum onlara özgü olmayıp Sünnî düşüncede yöneticilerle samimiyet kurmayı yakışıksız bulan geleneği yansıtmaktan öte bir anlam taşımaz. Hagiografik yazın, geçmiş din büyüklerini ölüm pahasına yöneticiler karşısında doğruyu söylemekten çekinmeyen cesur insanlar olarak tanıtan betimlemelerle doludur. Başka kaynak türlerinde de yöneticilerle dostluk kurmayı, onları ziyaret etmeyi ya da kadılık yapmayı zemmeden din âlimleri ile ilgili pek çok hikâyeye tesadüf etmek mümkündür. Bu hikâ-

Ebû Yûsuf, er-Red 'alâ Siyeri'l-Evzâ'î, Lecnetü İhyâ'i'l-Ma'ârifi'l-Nu'maniyye, Haydarâbâd Dekken bt. yok, s. 76 .

39 Ebû İshâk el-Fezârî, Kitâbu’s-Siyer, Müessesetü'l-Risâle, Beyrut 1987, s. 219.

40 Ebû İshâk el-Fezârî, age., s. 255-256.

41 İbn Ebî Ya‘la, age., C II, s. 35.

42 Aynı kaynaktaki başka bir rivayet göreyse neden Şam'a geldiğini soran birine İbrahim "helal para kazanmak için” cevabı verir: İsbehânî, age., C VI, s. 217.

43 Tor, age., s. 48 vd.; Bonner, age., s. 100-101; Sahner, age., s. 177. 
yelerde din âlimi, halifenin dinî-siyasî otoritesine meydan okuyan değil basitçe onunla yakınlık kurmayı tercih etmeyen biri olarak tasvir edilir. Üstelik çelişki gibi gözükmesine rağmen halifeye itaat, Sünnî din âlimlerinin en hassas oldukları konulardan biridir ve bu konunun Sünnî hadis koleksiyonlarında bazen cihat başlı̆̆ altında ele alındığını görmek çok anlamlıdır:

"Bana itaat eden Allah'a itaat etmiştir. Bana isyan eden Allah'a isyan etmiştir. Emire isyan eden bana isyan etmiş̧ir. Devlet başkanı ondan güç alınarak savaşılan ve onun sayesinde korunulan bir kalkandir ${ }^{44}$."

"Savaş iki türlüdür: [Ilki] Allah’ın rızasını isteyen, devlet başkanına (imâm) itaat eden, [cihat yolunda] bol harcama yapan ve fesattan kaçan[in yaptı̆g savaştır]. Bu kişinin uykusu da uyanıklı̆̆ da sevaptır. [Diğeri ise] gösteriş ve şöhret için savaşan, devlet başkanına isyan eden ve yeryüzünde fesat çıaran kişi[nin savaşıdır]. O kişi [evine] cihattan beklenen sevapla ile dönmez ${ }^{45}$."

Bir diğer örnekte devlet başkanı tarafindan atanan komutana itaatin önemi bir Kur'ân ayetiyle (4:59) ifade edilmiştir: "Ey iman edenler Allah'a itaat edin, Resulïne itaat edin ve ülü'l-emre itaat edin." Nesâî ve Ebû Dâvûd ayetin Hz. Muhammed'in bir müfrezeye komutan tayin ettiği biri (Abdullah b. Huzâfe veya Abdullah b. Kays) hakkında nâzil olduğunu naklederler ${ }^{46}$. Buhârî̀nin Sahîh'inde "kişinin gazveden dönmek veya geri kalmak hususunda devlet başkanindan izin istemesi" başlığı altındaki fikhî hüküm de yine bir ayetle (24:62) desteklenir: "Müminler ancak Allah ve Resulüne iman edenlerdir ve onunla ortak bir iş için toplanmış iken kendisinden izin almadan çekip gitmeyenlerdir. Senden izin isteyenler, evet işte onlar Allah'a ve Resulüne hakkıyla iman edenlerdir. Bazı özel işlerinden dolayn senden izin istediklerinde onlardan dilediğine izin ver ve Allah'tan onlarn bağı̧̧lanmasm dile $e^{47} \ldots$. Ordu komutanı ya da devlet başkanının komutası altında cihat yapmaya atfedilen öneme dair belki de en ilginç kayıtlar, saftan çıkıp düşmanla savaşırken ölen kişinin şehitliğinin geçersiz olduğunu ifade eden hadis ve haberlerdir ${ }^{48}$.

Burada can alıcı nokta, Tor ve Bonner'in cihadın ilan ve idaresi konusunda devlete meydan okuma tutumunu yaygin bir pratik olarak kabul ettiklerini varsaydıkları

44 Buhârî, age., C III, s. 1080; Nesâî, age., C V, s. 222-223; İbn Ebî Şeybe, el-Musannef fìl-Ehâdis ve’lÂsâr, C VII, Dârü'l-Fikr, Beyrut 1989, s. 566-567.

45 Nesâî, age., C IV, s. 432.

46 Nesâî, age., C IV, s. 432 ve C V, s. 223; Ebû Dâvûd, age., C IV, s. 264. Ayrica bk. İbn Ebî Şeybe, age., C VII, s. 567.

47 Buhârî, age., C III, s. 1083.

48 San'anî, age., C V, s. 177, 179. 


\section{Olarak Savaş İdaresi}

gönüllülerin; genel olarak hadisçiler, özel olarak Ahmed b. Hanbel (ö. 241/855) ya da onun yakın çevresiyle bağlantılı olduklarını iddia etmeleri ${ }^{49}$, ama Hanbelilerin cihadı bir devlet mesuliyeti olarak gören klasik görüşten uzaklaştıklarına dair işaretlerin olmamasıdır. Öncelikle hadisçilikle savaşçılık arasında bir ilişki kurabilmek için hadisçiler arasında aktif olarak cihatla meşgul olan kişilerin yüzdesini belirlemeye yönelik istatistiki bir çalışma yapmak ve yüksek bir yüzde bulmak gerekir ki adı geçen yazarlar son derece meşakkatli olan böyle bir çalışma yapmamışlardır. Tespit edilebilen az sayıdaki isim üzerinden genelleme yapmaksa bir metodoloji hatası içerir. Bir hadisçi için seyahat her şeyden önce dönemin hadis otoritelerinden hadis dinlemek ya da öğrenmek ereğiyle ilişkilidir ki örneğin şeyhü'l-muhaddisîn (hadisçilerin şeyhi) olarak tanınan Yahyâ b. Ma în'e (ö. 233/848) göre "sünneti savunmak Allah yolunda cihattan efdaldir ${ }^{50}$." Ayrıca Ahmed b. Hanbel, suğûr da dahil olmak üzere yaptığı yolcukların sebebini "ilim ve sünnet talep etmek" olarak izah etmiştir ${ }^{51}$. Daha da önemlisi onun gibi siyasî otoritelerle sorunlu ilişkileri olan bir din âlimi bile devlet otoritesini, kamusal ibadetlerin yürütülmesi ve dârü'l-İslâm'n savunulması için elzem olarak görmüştür ${ }^{52}$. Tabakâtii'l-Hanâbile'de İbn Hanbel'e "ister adil ister fâcir olsun cihat imamlarla birlikte geçerlidir; ne zalimin zulmü ne de adilin adaleti onu iptal eder 53" ve "cihat Allah' in Peygamber'i gönderdiği zamandan Deccâl ortaya çıknncaya kadar sürecektir. Zalimin zulmü ona zarar vermez ${ }^{5 \text { " " }}$ sözleri atfedilir. Halku'l-Kur'ân doktrinini reddettiği için hükûmet tarafindan sorgu ve gözetim altında tutulduğu dönemde bile selefin ittifak ettiği hususlar arasında kadere iman ve cidâli red gibi Hanbeli mezhebine ait itikadî inançların yanında "ister fâcir ister adil olsun tüm halifelerle cihat yapmayl" da göstermiştir ${ }^{55}$. İbn Hanbel'in öğrencilerinden Ebû Zür'a (ö. 264/878) "bize göre Cuma namazı ve cihat, ister adil ister fâcir olsun valilerden kime bu görev verilmişse onunla birlikte ifa edilir" sözleriyle ${ }^{56}$ hocasını izinden gider. Aynı şey Ahmed b. Hanbel'in bir diğger takipçisi Hasan b. Ali el-Berbehârî (ö. 329/940-941) için de geçerlidir:

49

Tor, age., s. 45, 66 .

Zehebî, Siyer, C III, s. 4202, 4214.

İbn Ebî Ya'la, age., C I, s. 49.

John Kelsay, "Comparison and History in the Study of Religious Ethics: An Essay on Michael Cook's Commanding Right and Forbidding Wrong in Islamic Thought", fournal of Religious Ethics, 35/2 (2007), s. 357.

İbn Ebî Ya'la, age., C I, s. 30.

İbn Ebî Ya'la, age., C I, s. 272.

İbn Ebî Ya'la, age., C I, s. 123-124.

İbn Ebî Ya‘la, age., C I, s. 193. 
“İmamları dinlemek ve onlara itaat etmek Allah'ın sevdiği ve razı olduğu şeylerdendir. Kim icmâ ve [ümmetin] rızası ile halife olmuşsa Müminlerin Emiri odur. ... Hac ve cihat imamla [ise] geçerlidir. Cuma namazı onların arkasında kılınırsa geçerlidir. ... Ahmed b. Hanbel de böyle derdi. ... Sultanın zulmü, Allah’ın farzlarından hiçbir farzı eksiltmez. Onların zulmü kendilerinedir. Senin onlarla olan gönüllülügün ve zühtün tam olsun, yani cemaatten ayrılma, Cuma namazını onların arkasında kıl, cihadı onlarla yap. Bunlarm hepsi de itaattendir ${ }^{57}$."

Sadece Hanbelilikte değil, genel olarak Sünnî İslam dünyasında din ve ahlâk standartlarına uymayan (câir) bir imam ya da komutanın emri altında sefere gitmenin uygun olup olmadığı sorusuna verilen fikhî cevap genellikle olumludur ${ }^{58}$. Bu bakış açısına göre hükümdarın günahkârlığı onunla Allah arasındaki bir meseledir, ama İslam beldelerini düşmandan koruma görev ve gayreti Müslümanların genel refahıyla ilgili bir konudur. Bu konuda örnek oluşturması için geçmişte salih ve dindar insanların, halife Yezîd b. Muâviye, zalimliği ile tanınan vali Haccâc b. Yûsuf ya da genel olarak Emevilerin emri altında cihada katıldıkları anlatılır ${ }^{59}$. Ehl-i sünnetin cihat ve kamusal ibadetlerin zalim dahi olsa imamla (halife) olduğu görüşü, Hanefî muhaddis Kelâbâzî'nin (ö. 380/990) tasavvufun Sünnîlik ile uyumlu bir dindarlık modeli olduğunu ispat etmek üzere kaleme aldığı et-Ta'aruf'ta şu sözlerle ifade edilir: "[Sûfiler], özrü olmadıkça her Müslümanın Cuma, cemaat ve bayram namazlannı ister adil ister günahkâr olsun imamlarn arkasında kılınacağ , cihat ve haccın da yine onlarla birlikte olduğu görüşündedirler ${ }^{60}$." Özetle Sünnî hadis koleksiyonları ve fikıh kitaplarının imama itaat konusuna ayırdıkları geniş bahisler, dahası bazen bu bahislere cihat başlı̆̆ı altında yer verilmesi, hadisçiliğin imamın meşruiyetini sorgulayan bir muhalefet biçimi olduğu şeklindeki varsayımın geçerliliğini kuşkulu hale getirir.

Gönüllü din savaşçıları ve onların liderlerine atfedilen zühtçülük özelliğine gelince; bu vurgu sanki züht hayatı ile savaşçılık arasında güçlü bir bağ varmış gibi bir

İbn Ebî Ya'la, age., C II, s. 19-20, 31.

Bonner, age., s. 50; ayrica bk. İbn Ebî Şeybe, age., C VII, s. 687-688; Şeybânî ve Serahsî, age., s. 110-113; San'ânî, age., C V, s. 278-280; İbn Hazm, age., C VII, s. 299-300; Ayrıca bk. David Cook, Understanding Jihad, University of California Press, 2005, s. 58.

59 Şeybânî ve Serahsî, age., s. 113; San'anî, age., C V, s. 279. Büyük günah işlese bile cihadın ancak imamla yapılacağını ifade edenlerden biri de Mısırlı muhaddis Abdullah b. Sâlih el-Mısrî'dir (ö. 223/838): Zehebî, Siyer, G II, s. 2405.

60 Kelâbâzî, Kitâbu't-Ta'arruf li Mezhebi ehli't-Tasavvuf, Mektebetü'l-Hâncî, Kahire 1994, s. 33. 


\section{Olarak Savaş İdaresi}

algı oluşturur. G. Sahner bu konuda daha da ileri giderek İslam'ın, Hristiyan aziz ve keşişlerin zühtçülük ve savaşçılıkla karakterize olan yaşam biçimlerini miras aldığını iddia eder ve buna delil olarak, Müslüman olup hayatını cihada adayan birkaç keşişi ve "ümmetimin ruhbanlı̆̆ cihattı" hadisini gösterir. Sahner'in bu hadiste tavsiye edilen yaşam biçimini benimseyenlere örnek olarak gösterdiği tek bir isim vardır: Abdullah b. el-Mübârek ${ }^{61}$. H. Neale de zühtçülük ve cihat arasında varolduğuna inandığı yakın ilişkiyi yine tanıdık isimler üzerinden izah etmeye çalışır: Abdullah ve İbrahim ${ }^{62}$. Gerçekten de her iki isim de cihadı bir züht pratiği olarak kabul etmiş ve uygulamış olabilirler. Ancak bu iki mefhum arasında zorunlu bir bağ olduğunu iddia edebilmek için çok daha fazla isme ihtiyacımız var. Yukarıdaki hadis, cihadı zühtçülüğün vazgeçilmez şartlarından biri haline getirmeye yetmemiştir ki hem Sahner hem de Bonner ${ }^{63}$, Orta Çă̆ İslam dünyasında cihat ve züht arasındaki ilişkiyi sıkıntılı bulan kişiler olduğunu kabul eder ${ }^{64}$. Abdullah b. Mübârek'in cihada bir züht pratiği olarak atfettiği önemin bile sınırları vardır. Tor, onun Kitâbu'z-Zühd ve Yelîhi Kitâbu'r-Rekâ'ik adlı çalışmasını ehl-i hadis dindarlığının cihat ve sünnet biçimini almassna iyi bir delil oluşturduğunu düşünür. Ama Abdullah burada cihadı züht hayatının olmazsa olmaz bir parçası olarak takdim etmemiştir. Kitapta cihadı konu olan beyanlar, onun yaygın bir züht pratiği olarak kabul edildiğini düşündürecek kadar fazla değildir ki biyografik ve hagiografik yazın üzerine basit bir taramada, istisnalar olmakla birlikte savaşçılığın zühtçülerin karakteristik özelliği olmadığı rahatlıkla görülür. Dahası aynı hagiografik gelenekte cihat yapmayan zühtçülerin idealize edildiği hikâyelere rastlanır. Böyle bir örnekte Ahmed b. Hadraveyh (ö. 240/854) gazaya çıkmayı çok arzulayan biri olarak takdim edilir, ama hikâyenin devamında eğer gazaya çıkarsa sıkı şekilde riayet ettiği oruç ve gece ibadetlerini ihmal edeceği, uzlet halinden çıkacağı için bunun aslında nefsinin ona oynadığı bir oyun olduğunu farkedip evinde oturmayı tercih eder. Başka bir kayıtta ise Mâlik b. Dinâr'ın hastalandığı için çok arzuladığı halde gazaya çıkamadı̆̆ı, ama bu sayede helak olmaktan kurtulduğu anlatılır. Hikâyeye göre gazaya çıkamadığı için üzülen Mâlik bir ses işitir. Bu ses ona eğer gazaya çıksaydı esir düşeceğini ve kâfirlerin ikram ettiği domuz etinden yemek zorunda kalıp küfür ehlinden biri olacă̆ını söyler ${ }^{65}$. Bu son rivayet yukarıda Fudayl'ın Mekke halkına uyarı olsun

61 Sahner, a.g e., s. 175-177.

62 Neale, age., s. 94-96.

63 Sahner, age., s. 182.

64 Bonner, age., s. 50

65 Her iki hikâyeyi de Tezkiretü'l-Evliyâ'dan iktibas eden Neale, age., s. 102-103. Mâlik'e ayrıca “cihat 
diye anlattığı, Tarsus'a gidip gaza yapmayı çok isteyen, ama sonunda esir düşüp Hıristiyan olan adamla ilgili hikâyeyi hatırlatıyor.

Bu arada tasavvuf literatürünün bir züht pratiği olarak gösterdiği seyahatin (sefer) zorunlu olarak cihat ereğiyle ilişkilendirilmediğini not etmek gerekiyor. Örneğin Kelâbâzî, dinî bir buyruk ve tasavvufun esaslarından biri olarak gördüğü seferin gayesini nefsi terbiye etmek ve ibret almak olarak izah etmiştir ${ }^{66}$. Sülemî (ö. 412/1021) için seyahatin anlamı farklıdır, ama yine cihat ereğiyle ilişkili değildir: "Mücâhedeler seyahatlerde ortaya çıkar. Seyahat ise iki türlüdür. Nefsin seyahati Allah dostlarm görmek veya Hakk'n kudretinin eserlerinden ibret almak gayesiyle yeryüzünde dolaşmaktr. Kalbin seyahati ise melekût aleminde dolaşarak kişiye gaybrn müssahedelerinin bereketlerini göstermek içindir ${ }^{67}$." Ebû Tâlib el-Mekkî̀nin (ö. 386/996) Kûtii'l-Kulûb'unda da konuyla ilgili ilgi çekici anekdotlar bulunur: Ebû Türâb en-Nahşebî̀ye (ö. 245/859) -ribâtlarıyla meşhur olan- Abbâdân'daki namazın hükmü sorulur ve o Mescid-i Haram'daki uykunun Abbâdân'daki namazdan daha hayırlı olduğunu söyler. Rivayetin devamında başka bir sufinin bütün serhat boylarının Abbâdân'a, Abbâdân'ın ise Cidde'ye yöneldiğini gördüğü için kendisinin de Mekke'de mücâvir olarak yaşamaya karar verdiği anlatılır ${ }^{68}$. Ebû Tâlib el-Mekkî ayrıca Mekke, Medine ve Kudüs dışındaki bütün şehirlerin eşit olduğu şeklinde bir yorumda bulunur. Ona göre teşvik edilen ve fazileti sebebiyle gidilmesi istenen başka bir belde yoktur ve bunlar dışındaki beldeler için herhangi bir şerî̀ hüküm mevcut değildir. el-Mekkî devamında şu hadisi aktarır: "Binekler ancak şu üç mescit için koşturur: Mescid-i Haram, Mescid-i Nebevî ve Mescid-i Aksấ."

Öte yandan züht ve tasavvuf literatüründe cihada "Allah yolunda silahlı mücadele dışında" başka manalar atfedilmiştir. Bu literatürde bilhassa nefse ya da şeytana karşı savaşmanın da bir tür cihat olduğu anlayışı yaygındır ${ }^{70}$. Bu düşünce, $\mathrm{Hz}$. Muhammed'in bir gazve dönüşü zikrettiği söylenen "kü̧̈ük (silahli) cihattan büyük cihada (nefisle mücadele) döndük" sözlerini referans gösterir. Kütüb-i Sitte'de yer almayan

diyip duruyorlar, ben nefsime karşı cihattayım" sözleri atfedilir: İsbehânî, age., C II, s. 255.

66

67 


\section{Olarak Savaş İdaresi}

hadisin geçtiği mevcut en erken kaynak 5/11. yüzyıla aittir ${ }^{71}$. Ne var ki, cihadın illa kılıç ile olması gerekmediği anlayışının çok daha eski olduğu görülür. Örneğin Muhâsibî (ö. 243/857) çok ibadet eden ya da cihat yapan kişinin; korku, şükür, nefis terbiyesi, tevbe ile Allah'a yaklaşan kişinin mertebesine erişemeyeceğini söylüyor, cihat yapanları ilimleriyle amel etmedikleri için küçümsüyor, insanların nefis muhasebesi yapmak yerine düşmanla mücahedenin daha hafif olduğu yolları (yani silahlı cihat) seçtiğini söylüyordu ${ }^{72}$. Ne ilginçtir ki Abdullah b. Mübârek'de de aynı düşüncenin izlerini görmek mümkündür. $\mathrm{O}$, Kitâbü'z-Zühd'de "mücahit Allah'a itaat etme uğrunda nefsiyle cihat eden kimsedir" şeklinde bir hadis nakletmiş ${ }^{73}$, ribâta farklı manalar (sabretmek, namaz saatini beklemek) atfeden ${ }^{74}$ ve Allah'1 zikretmenin cihada eş ya da ondan efdal olduğunu beyan eden haberlere ${ }^{75}$ yer vermiştir.

\section{Gönüllülerin Bağımsızlıkları Meselesi}

Gazaya çıkmak ya da ribât için elbette ki orduya yazılmak gerekmiyordu. Bu şekilde savaşa gidenler başta da ifade edildiği gibi her ikisi de gönüllüler anlamına gelen muttavi $^{6} a$ ve mutatavvi ${ }^{6} a$ terimleriyle ifade edildiler. Peki onlar gerçekten de halife ya da onun komutanlarından gelen talimatlara aldırmayan askerler miydi? Herevî (ö. 433/1041) gönüllüleri "hükümdarın zorlaması olmadan cihada gidenler" şeklinde tanımlar ${ }^{76}$. Sem ‘̂nî ise gönüllü askeri, "mecbur olmadığı halde kendini gaza yapmaya adayan ve suğûrda ribât yapan kişi” olarak betimler ${ }^{77}$. Benzer şekilde Şâfi î de savaşa katılmama mazareti olanlar ya da üzerine farz olmadığı halde gazaya çıkanlar için bu terimi kullanır" ${ }^{78}$ Şâfîi aynı kitabın başka bir yerinde sultandan aldığı ücretle gaza yapanlar ve masraflarını başka şekilde karşılayanlar şeklinde bir ayrım yapar. İkinci grubun istedikleri zaman evlerine geri dönme konusunda

71 Neale, age., s. 4.

72 Muhâsibî, Âdâbu'n-Nufûs yelîhi Kitâbu't-Tevehhüm, Müessesetü'l-Kütübi’s-Sekâfiyye, Beyrut 1991, s. 115-116.

73 Abdullah b. el-Mübârek, Kitâbu'z-Zühd ve Kelîhi Kitâbu'r-Rekâik, Dârü'l-Kütübi'l-'İlmiyye, Beyrut bt. yok, s. 284-285.

74 Abdullah b. el-Mübârek, Kitâbu'z-Zühd, s. 137-138.

75 Abdullah b. el-Mübârek, Kitâbu'z-Zühd, s. 105-106, 122, 394, 398. Bu arada Sıfatü's-Safve'de Abdullah b. el-Mübârek'in aile için helal para kazanmayı cihattan üstün tuttuğuna dair bir anlatı bulunur: İbnü'l-Cevzî, age., C II, s. 326.

76 Herevî, Kitâbu İsfâri'l-Fasîh, C II, İmadetü'l-Bahsi'l-'İlmî, Medine 1420, s. 879.

77 Sem‘ânî, age., C XII, s. 317.

78 Şâfi'î, el-Ümm, C V, Dârü'l-Vefâ, 2001, s. 370.

Belleten, Aralık 2021, Cilt: 85/Sayı: 304; 819-848 
-belirli şartlara bağlı olmakla birlikte- biraz daha geniş hakları vardır ${ }^{79}$. Yani savaşa iştirak etmede olduğu gibi eve dönme konusunda da onlara daha geniş bir esneklik tanınmıştır ${ }^{80}$.

Yukarıdaki tanım ve izahlar, gönüllülerin savaş sırasında diledikleri gibi hareket edebildikleri ve hilafet ordusundan tamamen bağımsız oldukları ile ilgili herhangi çıkarıma izin vermez. Savaşta gönüllü olmanın anlamı, mecburiyet olmadığı halde kişinin kendi atı ve ekipmanıyla savaşa katılması ve istediği zaman eve dönme özgürlüğüne sahip olmasıyla sınırlıydı. Gönüllü askerin savaşma konusunda devlet zorlamasına maruz kalmaması, savaş sırasında devlet otoritesinden tümüyle bağımsız hareket ettiği anlamına gelmiyordu. İbn Manzûr (ö. 711/1311) gönüllüleri ordu divanına kayıtlı olmayan, ama hizmetleri karşılığında bahşiş alan gaza gönüllüleri olarak tanımlar $\mathrm{ki}^{81}$ bu bahşişi veren hükûmettir ${ }^{82}$. Ama aslında gönüllülerin kazancı bahşişin çok ötesinde olabilir. Zira baş kadı Ebû Yûsuf (ö. 182/798) gönüllülerin ve muvazzaf askerlerin (sâhibu'd-divân) ganimet taksiminde eşit olduklarını söylemiştir ${ }^{83}$. Bu arada dinsel motivasyon bakımından da iki askerî sınıf arasında muazzam farklılıklar olduğunu gösteren işaretler yoktur. İbnü'l-Mülakkın (ö. 804/1401) ilim ehlinin gönüllüler mi yoksa maaşlı askerler mi efdaldir sorusu üzerine ihtilaf ettiklerini, cumhurun gönüllülerin daha üstün olduğu görüşünde olduğunu, çünkü maaşlı askerlerin suğûra emirle gittiklerini söyler ${ }^{84}$. Ancak zorlama olmadan savaşa katılmaları-zahit-savaşçlar bir kenara konacak olursa- gönüllülerin her zaman ve her durumda onları düzenli orduyu oluşturan askerlerden farklı kılan özel bir dinî motivasyona sahip oldukları anlamına gelmez. Ganimet bir geçim şekli olarak sınıra gitmek için yeteri kadar çekici bir sebeptir.

İslam dünyasının farklı bölgelerinden gelen gönüllü savaşçların siyasî otoritelerle cihat hususunda rekabet halinde olduklarına ve imamın otoritesini sorguladıklarına dair veriler olmadığı gibi, halifelerin de gönüllülerin bir çeşit ibadet telakki ettikleri cihat meşgalelerine müdahale ettiklerini ya da bundan rahatsızlı duy-

Şâfíî, age., C V, s. 373-374.

İbn Manzûr, age., C XI, s. 672.

Belleten, Aralık 2021, Gilt: 85/Sayı: 304; 819-848

Kendisine gönüllülerin mi yoksa muvazzaf askerlerin mi (ashâbu'd-dî̀ân) daha üstün oldukları sorulan eş-Şa ‘bî (ö. 104/722) "muvazzaf askerler”" cevabını verir, zira gönüllüler isterlerse savaşmaktan vazgeçip ülkelerine geri dönebilmektedirler: San'ânî, age., C V, s. 279.

Maverdî, Kitâbu'l-Ahkâmi’s-Sultâniyye, Dârü'l-Fikr, Beyrut bt. yok, s. 36.

Ebû Yûsuf, Kitâbu'l-Harâc, el-Mektebetü'l-Ezheriyye li’t-Türâs, Kahire 1999, s. 29.

İbnü'l-Mülakkın, et-Tavzîh li-Şerhi'l-Câmi'i’s-Sahîh, C XXII, Dârü’n-Nevâdir, Dımaşk 2008, s. 258. 


\section{Olarak Savaş İdaresi}

duklarını gösteren kanıtlar bulunmamaktadır. Tersine, gönüllülerin savaşa kendi ekipmanları ile katılması ve devletten maaş almayıp bahşiş ve kendilerine düşen ganimet payı ile yetinmeleri onları oldukça çekici kılmış olmalı. Zorunlu askerlik uygulamasının olmaması, bilhassa asker ihtiyacı duyulan dönemlerde gönüllü birliklerin sorunsuzca düzenli orduya entegre edilebilmiş olmasını gerektirir. İlk Abbasi halifeleri Bizans sınırındaki yerleşimlere ikâmeti teşvik için fazla maaş, ikta ve ev bağışı gibi imkânlar sunmuşlar, ayrıca sınır bölgesinde harap şehir ve surların yeniden imarı gibi başka yatırımlar yapmışlardır ${ }^{85}$. Bu durum erken Abbasi döneminde bu bölgede asker eksikliği olduğunu gösterir ${ }^{86}$. Nitekim sorunun üstesinden gelmek için bölgeye Şam ve Horasan vilayetlerinden sürekli asker takviyesi yapılmıştır. İbn Havkal (ö. 4/10. yüzyıl) kendisine Tarsus'un geçmişteki durumuyla ilgili bilgi veren birçok siyasetçi ve âlimle tanıştığını, onlardan duyduğuna göre bir zamanlar bu beldenin Mağrib'den Yemen ve Sicistan'a kadar imparatorluğun değişik şehir ve bölgelerinden gelen binlerce askerle ( $g a \hat{z} \hat{\imath})$ dolu olduğunu, bu askerlerin geçim ve ikâmeti için sultanların cömert yardımlar yaptıklarını, aynı maksatla çiftlik, ev, han ve hamamlar vakfettiklerini ifade eder ${ }^{87}$. Hazineden yardım görmeyen gönüllülerin hele hele fetihlerin hız kaybettiği dönemlerde sinır şehirlerinde ikâmet etmeye devam ettiklerini hayal etmek zordur. Nîşâburlu din âlimi İbn Huzeyme'nin (ö. 311/924) Tarsus'taki insanların düşman saldırısından muzdarip olup kaçması üzerine ağlayarak suğûra gittiği, hazinede para olmadığı için arazisini satıp on gönüllü gaziyi teçhizatlandırdığı söylenir ${ }^{88}$. Gönüllülerin divana kayıtlı olmamakla birlikte devletle koordineli şekilde çalıştıklarına dair başka bir kayıt, Muhammed b. Yûsuf el-Kindî (ö. 350/961) ve İbn Hacer el-Askalânî'den (ö. 852/1449) gelir. Buna göre, Mısır'da 3/9. yüzyılda gönüllüler ve orduya kayıtlı askerlerin kaldıkları evler bulunmakta, her yıl vakıflarda biriken para bu askerlerin geçimine tahsis edilmektedir ${ }^{89}$.

Gönüllüleri tamamen bağımsız bir askerî güçmüş gibi takdim eden araştırmacılar, onların Emevi döneminden itibaren hilafete bağlı düzenli ordularla birlikte sefe-

85 Kudâme b. Ca'fer, Kitâbu'l-Harâc ve Sinâ'atü'l-Kitâbe, Dârü’r-Reşî̀d lî’n-Neşr, 1981, s. 308- 310.

86

Başka yerlerde de benzer bir sorunla karşılaşılabiliyordu. Abbasi halifesi el-Mansûr Deylem'de çıkan bir isyan üzerine Basra valisine haber göndererek şehirde on bin dirhemden fazla parası olan kişileri belirlemesini ve onlara cihat için yola çıkma emri vermesini bildirmişti: Taberî, age., s. 1511.

87 İbn Havkal, Kitâbu Sûreti’l-Ard, Dâru Sadır, Beyrut bt. yok, s. 183-184.

88 Sem‘ânî, age., C III, s. 81.

89 Kindî, age., s. 300; İbn Hacer el-Askalânî, age., s. 312. 
re çıktıklarını söyleyen kayıtları görmezden gelirler. Örneğin, Emevilerin Mağrib valisi Mûsâ b. Nusayr (ö. 98/717) Sanhâce kabilesine, dört bin ordu divanına kayıtlı asker ve iki bin gönüllü ve Berberi muharip ile birlikte saldırmışıır ${ }^{90}$. Talas Savaşı'nda Çin ordusu ile karşı karşıya gelen Abbasi ordusu içinde gönüllüler de vardır ${ }^{91}$. 159/775 yllında halife el-Mehdi'nin Hind'e sefer düzenlemesi için oluşturduğu ve başına Abdülmelik b. Şihâb’ı getirdiği ordu dört kısımdan oluşup bunlardan ikisi gönüllü birliklerdir. Bu gönüllü birliklere komutanlık yapacak iki kişi bizzat Abdülmelik tarafindan seçilir ${ }^{92}$. Halife el-Mehdi'nin komutanlarından Hasan b. Kahtabe'nin 162/778 yllında Horasan, Musul, Şam halkı, Yemen yardımcı kuvvetleri ve Irak ve Hicaz gönüllülerinden oluşan ordusuyla Rum ülkesine gazaya çıktığı söylenir. Rivayeti veren Belâzürî devamında Hasan b. Kahtabe’ye bu gazve esnasında Kûfeli muhaddis Mendel el-'Anezî ve Basralı muhaddis Mu'temir b. Süleyman'ın da eşlik ettiğini söyler ${ }^{93}$. Yine Belâzürî’nin söylediğine göre, el-Mehdi halife olunca Masîsa'ya iki bin asker göndermiş, ancak eldeki topraklar daha önceki asker ve gönüllülere dağıtıldığı ve yeterince toprak kalmadığı için bu yeni gelen askerlere toprak bağışı yapamamıştır ${ }^{94}$. Hârûn er-Reşîl'in henüz veliahtken Bizans topraklarına düzenlediği bir yaz seferinde orduda gönüllüler de vardır ${ }^{95}$. Yine o 183/800 yılında inşa ettirdiği Hârûniyye şehrine savaşçllar ve gönüllülerden oluşan bir grup yerleştirmiştir ${ }^{96}$. Zehebîye bakılırsa, Herakleia'nın fethi sırasında Hârûn er-Reşîd'in ordusunun neredeyse yüzde otuzunu gönüllüler oluşturmuş̧ur ${ }^{97}$. el-Me'mûn'un Bâbek isyanını bastırmak için oluşturduğu orduya Basra, Hicaz, Ummân, Bahreyn, Fars ve Ahvaz'dan gönüllüler de iştirak etmiştir ${ }^{98}$.

90 İbn Kuteybe, el-İmâme ve’s-Siyâse, Dârü'l-Kütübi'l-'İlmiyye, Beyrut 2006, s. 231.

91 Makdisî, Kitâbu'l-Bed' ve't-Târîh, C VI, Mektebetü's-Sekâfeti'd-Dîniyye, by. ve bt. yok, s. 75 .

92 Taberî, age., s. 1609.

93 Belâzürî, el-Büldân, s. 199. Bu olayla ilgili benzer kayıtlar için bk. Taberî, age., s. 1620 (bu kayıtta maaşlı askerler gönüllülerden mürtezika مرنزقة tabiriyle ayrılır); İbnü’l-Esîr, age., s. 847; Zehebî, Târîhu'l-İslâm, G IV, s. 273; İ̉nü'l-Cevzî, el-Muntazam fî Târîhi'l-Ümem ve'l-Mülûk, G VIII, Dârü'l-Kütübi'l-'Illmiyye, Beyrut 1992, s. 256; Kudâme b. Ca'fer, age., s. 310.

94 Belâzürî, el-Büldân, s. 195; Kudâme b. Ca'fer, age., s. 308. Taberî, age., s. 1625; Makdisî, age., C VI, s. 96; İbnü'l-Cevzî, el-Muntazam, C VIII, s. 277-278.

Kudâme b. Ca'fer, age., s. 311

Zehebî, Târîhu'l-İslâm, C IV, s. 792; İbnü'l-Cevzî, el-Muntazam, C IX, s. 181.

Anonim, el-'Uyûn ve'l-Hadâ'ik, Brill, Leiden 1871, s. 373. Başka örnekler için bk. Taberî, age., s. 1609, İbnü'l-Esîr, age., s. 844, 990, 1098, 1106, 1167; İbnü'l-Cevzî, el-Muntazam, C VIII, s. 236 Ayrıca bk. C. E. Bosworth, "The City of Tarsus and Arab-Byzantine Frontiers in Early and Middle 'Abbāsid Times”, Oriens, 33 (1992), s. 271-272; Taberî, age., s. 1844-1845; İbnü’l-Esîr, age., s. $1844-1845$. 


\section{Olarak Savaş İdaresi}

Fezârînnin Abbasi otoriteleriyle birlikte savaşa katıldığını söyleyen kayıtlar çok daha çarpıcıdır ve Tor ve Bonner tarafindan fark edilmemiştir. Böyle bir kayıtta Fezârî ve Mahled b. el-Hüseyin'in -ki o Zehebî’nin “sınırın şeyhi”" (şeyhu's-sağr) diye tavsif ettiği biridir ${ }^{99}$ - Herakleia'nın fethi sırasında halife Hârûn er-Reşîd ile birlikte oldukları söylenir. Mes'ûdî (ö. 345/956) bu haberi "Şam suğûrunun şeyhi" olarak isimlendirdiğ $1^{100}$ bir savaşçı ve hadisçi olan Ebû 'Umeyr 'Adî b. Ahmed'den duyduğunu belirtmiştii ${ }^{101}$. Fezârî ve Mahled'in, Hârûn er-Reşîd ile savaş stratejisi konusunda istişare ettiklerini söyleyen başka bir kayıt daha bulunur. Buna göre bir düşman askeri Müslüman savaşçları mübârezeye (duello) çağırır. Halifenin izni gerektiğinden kimse buna yanaşmaz. Hârûn durumdan haberdar edildiğinde yanında bulunan Mahled ve Fezârî ona ordusunun zaten cesurluğuyla tanındığını, mübârezede galip gelmenin onun askerleri için sıradan bir iş olduğunu, yenilgi olursa da bunun İslam ordusu için büyük bir ayıp olacağını söyleyip asker seçiminin kendilerine bırakılması ricasında bulunurlar. Halifenin onayından sonra Mahled ve Fezârînnin seçtikleri kişi, suğûrda cesaretiyle meşhur olan gönüllü savaşçı İbnü’l-Cezerî olur ${ }^{102}$. Bu rivayet hem Fezârî’yi hem de bir kez daha gönüllüleri halife ile birlikte savaşan kişiler olarak gösterir. Târîhu'l-Mevsll'da geçen başka bir rivayete göreyse Fezârî daha evvel, halife el-Mansûr döneminde Züfer b. 'Âsım'nn düzenlediği yaz seferine iştirak etmiştir ${ }^{103}$. Gönüllüleri devlet otoritesine meydan okuyacak şekilde örgütlediği iddia edilen kişilerden biri olan İbrahim b. Edhem’in de düzenli orduyla birlikte gazaya çıktığına işaret eden rivayetler bulunur. Böyle bir rivayette $o$, zühtçülügünden ve paraya tamah etmeyen biri olduğundan sadece ganimetteki payını değil aynı zamanda savaşçlara tahsis edilen maaşı da almayı reddeden biri olarak karşımıza çıkar. Ayrıca onun Masîsa kadısı Bişr b. el-Münzir ile birlikte gazaya çıktığını söyleyen bir kayıt vardır ${ }^{104}$.

\section{İş Birliği: Cihadın Farz-ı Kifâye’ye Dönüştürülmesi}

Ulemâ cihadın idare ve idamesi konusunda siyasî otoritelere meydan okumadığı gibi bu alanda bir devlet tekeli oluşmasına yardımcı oldu. Devlet tekelinden kas-

99 Zehebî, Siyer, C III, s. 3809.

100 Mes'ûdî, Mürûcu'z-Zeheb, Dârü İhyâi't-Türâsi'l-'Arabî, Beyrut bt. yok, C I, s. 214.

101 Mes'ûdî, age., C I, s. 221-222.

102 Kazvînî, Âsâru'l-Bilâd ve Ahbâru'l-'İbâd, C I, Dâru Sâdır, Beyrut, s. 556.

103 Ezdî, Târîhu'l-Merssl, C I, Dârü'l-Kütübi'l-'İlmiyye, Beyrut, 2006, s. 438. Fezârî ile Hârûn erReşîd arasındaki yakınlığa işaret eden bir rivayet için bk. İbn Ebî'd-Dünya, Kitâbu'l-Emr bi'lMa'rûf ve Nehy 'ani'l-Münker, Medinetü'n-Nebeviyye 1997, s. 107.

104 İsbehânî, age., C VI, s. 264. 
tedilen şey, savaş ilanı için resmi bir otoriteden emir gelmesi, savaşın bu otorite tarafindan idare edilmesi ve savaş boyunca ona itaat edilmesidir ${ }^{105}$. İbn Rüşd'e bakılırsa Hz. Muhammed zamanında hiç kimse ve hiçbir askerî birlik onun emri olmadan savaşa çıkmadığı için ulemâ buradan savaş için imamın emrinin şart olduğu sonucunu çıkarmışıı ${ }^{106}$. Gerçekten de kaynaklarda savaşın ilan ve idaresini devlet başkanına ait bir görev olarak tanımlayan pek çok bahse rastlanır. Hârûn er-Reşîd'in baş kadısı Ebû Yûsuf'un cihat üzerindeki devlet tekeline halifenin veya halife tarafindan tayin edilen kumandanın izni olmadan hiçbir yere asker, müfreze ve ordu gönderilemeyeceğini savunarak vurgu yaptığı görülür ${ }^{107}$. Aynı eserin başka bir yerinde emîrin (komutan) arkasında savaşmanın lüzumundan bahseder ${ }^{108}$. Benzer bir uyarı Ebû 'Ubeyd'den (ö. 224/838) gelir: "Kumandanm izni olmadan hiçbir ordu (seriyye) gazaya çıkarlamaz ${ }^{109}$." Ebû Yûsuf ve Ebû 'Ubeyd'in beyanları Abbasilere hizmet eden devlet memurları olmalarına bağlanabilir. Ama cihadın halifeyle ifa edilecek bir dinsel görev olduğu, hükûmetle böyle bir bağı olmayan Sünnî âlimler arasinda da yaygin bir kanıyd.

Sünnî âlimler bu konuyu Emevi ya da Abbasi hükûmetleriyle ilgili fikirlerinden bağımsız şekilde ele aldılar. Hasan el-Basrî’nin (ö. 110/728) Emevi yöneticileriyle arası iyi değildi, ama ona göre imamdan izin almadan savaşanların ganimet olarak aldıkları şey üzerinde hakları yoktu ${ }^{110}$ ya da sınırlıydı ${ }^{111}$. Üstelik o savaşçların ordudan ayrılıp ya da saftan çıkıp kendi başlarına savaşmalarını doğru bulmuyor$\mathrm{du}^{112}$. Yukarıda ifade edildiği üzere Evzấî tıpkı Hasan el-Basrî gibi düşünüyordu; yine tıpkı Hasan el-Basrî gibi yöneticilerle arası pek iyi olmasa da. Bu görüş, sonra gelen pek çok âlim tarafindan tekrar takrar kayda geçirildi. Örneğin hadis ulemâsından İbn Ebî Şeybe (ö. 235/849) komutanın izni olmadan saldırıya geçen bir müfrezenin ihanet etmiş sayılacağını söyleyen bir hadis ve iki ordu karşı karşıya geldiğinde komutanın izni olmadıkça kimsenin saldırıya geçemeyeceğini vur-

105 Mâlik b. Enes, el-Muvattâ, C II, Dâru İhyâi Türâsi'l-'Arabî, Beyrut 1985, s. 466; Şeybânî ve Serahsî, age., s. 62, 116; John Kelsay, "Al-Shaybani”, s. 69.

106 İbn Rüşd, age., s. 391-392.

107 Ebû Yûsuf, Kitâbu'l-Harâc, s. 217.

108 Ebû Yûsuf, Kitâbu'l-Harâc, s. 19.

109 Ebû 'Ubeyd, Kitâbu'l-Emvâl, C I, Dârü'l-Hedyi'n-Nebevî, Mansura 2007, s. 444.

110 Taberî, Kitâbu'l-Cihâd ve Kitâbu'l-Cizye ve Ahkâmu'l-Muhâribîn min Kitâbi İhtilâfi'l-Fukâhâ, Leiden 1933, s. 80; İbn Ebî Şeybe, age., C VII, s. 670, Maverdî, age., s. 141.

111 İbn Rüşd, age., s. 394.

112 San'ânî, age., G V, s. 181. 


\section{Olarak Savaş İdaresi}

gulayan haberler nakletmiş̧i ${ }^{113}$. Konuyu ele alan müelliflerden biri de Taberîydi (ö. 310/923). Onun İhtilâfu'l-Fukahâ' (Fakihlerin İhtilaf Ettikleri Konular) isimli çalışmasındaki "imamın izni olmadan düşman topraklarına girme" şeklindeki bir alt başlık kendi başına konu hakkında farklı görüşler olduğunu gösterse de Taberî; Evzâ‘î ve Şâfi'̂̀’nin imamdan izin almadan düşman topraklarına girmeyi hoş karşlamadıklarını ifade eden kayıtlar tutmuş, üstelik böyle bir şey vuku bulduğunda ele geçirilen ganimetteki beşte bir hissenin sultana ait olduğuna dair fikhî görüşler aktarmışıı ${ }^{114}$. Aynı çalışmanın başka bir yerinde mübârezeye davet edilen ya da çıkmak isteyen birinin dahi imamdan izin alması gerektiğine dair yine Evzaî ve ayrıca Süfyân es-Sevrî'ye ait fikhî görüşleri zikretmiştir ${ }^{115}$. Hakîm et-Tirmizînnin (ö. 320/932) konu hakkındaki yargısı daha nettir; zira Hz. Muhammed'in nehyettiği ameller üzerine yazdığı el-Menhiyyât'ta, devlet başkanının izni olmadan savaşmayı bu amellerden saymışı1"16. Ibn Hazm (ö. 456/1064) "devlet başkam bir kimseye dâru'l-harbe karşı cihat emrettiğinde cihada kathlmak o kimse için farzder" diyerek ${ }^{117}$ ehl-i sünnetin konu ile ilgili klasik görüşünü tekrarlamış olur. Aynı şey Maverdî (ö. 450/1058) için de geçerlidir: O, el-Ahkâmü's-Sultâniyye'de savaş idaresi başlı̆̆ını taşıyan bölümde yöneticilere ve komutanlara itaat konusuna özel bir önem vermiş, bunun dinî bir emir olarak görülmesini telkin etmiştir ${ }^{118}$.

Ulemânın cihadın ilan ve idaresini hükûmete bırakması ve onun bu alandaki otoritesinin sorgulanmasına izin vermemesinin birkaç sebebi olabilir. Öncelikle cihat, ancak toplu bir eylem olarak ifa edildiğinde başarı getiren, bireysel bir görev olamayacak kadar organizasyon ve yatırım gerektiren bir işti. Sayıları binlerle ifade edilen askerî birliklerin kontrolü, bir yerden bir yere sevki ve iaşesi devlet otoritesini zorunlu kılıyordu. Öte yandan devlet başkanı tarafından ilan ve idare edilen cihada katılmamak ya da ondan izin almadan cihat yapmak, bir bakıma onun dinî ve siyasî otoritesinin sorgulanması demekti. Nitekim cihat, İslam dünyasındaki pek çok dinî-siyasi hizip için dârï'l-harbe karşı savaşmaktan çok ya da onunla aynı öneme sahip bir iç direniş ideolojisi oldu. Örneğin Şiîlikte sadece kâfirin imansızlı̆̆ değil imama itaatsizliğin de cihat ilan etmeyi gerektirdiği hususunda

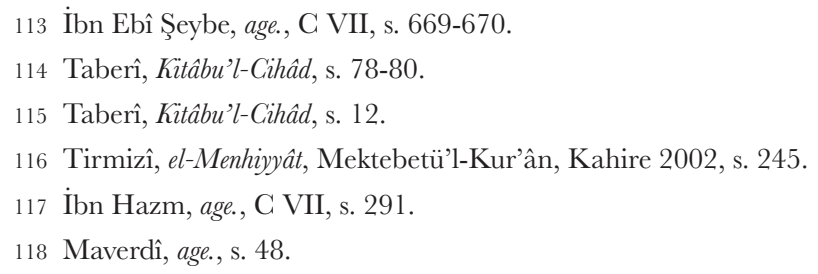


güçlü bir vurgu vardı ${ }^{119}$. Emevi ve Abbasi otoritelerini tanımayan Şia, cihadın zorunluluğunu Şiî bir imamla birlikte yapılması şartına bağlıyor ve ancak böyle bir savaşta ölmenin şehitlik getireceğine inanıyordu ${ }^{120}$. Hâricîler için de cihadın özel bir anlamı vardı; onlar cihadı İslam'ın şartlarından biri sayıyor, kendilerini şurât, yani “Kur'ân'da Allah'ın söz verdiği uhrevî ödül için hayatlarını satanlar" olarak isimlendiriyorlardı. Hâricîlerin cihat yorumu devletin, hele hele meşruiyeti olmayan bir devletin şiddeti kendi tekeline alamayacağı ve cihadın Allah'nn (sadece devlete değil) tüm Müslümanlara farz kıldığı bir ödev olması üzerine temelleniyor$\mathrm{du}^{121}$. İşte Sünnî ulemânın cihadın halifeyle olduğu görüşü üzerindeki ısrarı, başta Şia olmak üzere gitgide dogmatik bir aşırılığa sürüklendiğine inandığı mezhepler karşısında siyasi otoritelere itaati cemaatin birliği için ön şart olarak yorumlama noktasına gelmesiyle yakından ilgiliydi. Sünnî ulemâ, Şiî ve Hâricî cihat doktrinine muhtemelen, savaş çağrısına ancak resmi bir otoriteden gelmesi halinde icabet etmenin gerekli olduğu şeklinde karşlık verdi. Böylece cihadın devamını imamın varlı̆̆1 ve otoritesine bağlamak, sadece Şîiliğe değil Sünnîliğe de yerleşmiş oldu.

İmama itaatsizliği cihat nedeni sayma konusunda da Sünnîlik ve Şiîlik arasında paralellikler bulunur. Sünnî fakihler savaşa en başta İslam topraklarını genişletme, savunma ve İslam dinini yayma gibi meşru bir dava ya da haklı niyet söz konusu olduğunda cevaz vermekteydiler. Ama Sünnîlikte de bir iç cihat mefhumu kesinlikle vardı ve Şiîlikten farklı olarak gâsıp bir hükûmetten ziyade onun varlığını tehlikeye atan grupları hedef alıyordu: irtidâd edenler (çünkü dinden dönmek aynı zamanda siyasî bir başkaldırıştır), asiler (çünkü isyan ederek sadece hükümdara değil Allah'a da karşı gelmiş olurlar) ve eşkıyalar (çünkü Müslümanların rahatça ibadet etmelerini engellerler ${ }^{122}$. Görüldüğü üzere burada iç cihadın hedefi, şerîi kuralları ihlal eden ya da askıya alan hükûmet değil, cemaatin birliğinin garantörü olarak görülen siyasî otoritenin varlığını tehlikeye atan gruplardı. Ele geçirilmeleri halinde bunlar hakkındaki hükmün kadı değil devlet başkanına bırakılması ${ }^{123}$, Sünnî düşüncede cihadın ilan ve idaresinin ona tahsis edilmesiyle yakından ilgiliydi.

119 Macid Hadduri, İslam Hukukunda Savaş ve Barşs, çev. Fethi Gedikli, Yöneliş Yay., İstanbul 1999, s. 75.

120 Denis McEoin, "Aspects of militancy and quietism in Imami Shi'ism”, British Society for Middle Eastern Studies, $11 / 1$ (1984), s. 19-20; Bonner, age., s. 125. Şî̂likte cihat konusunda imama ya da onun temsilcisi olan emir-komutana itaat hakkında bk. Qadi Nu'man, The Kitāb al-fihād from Da'a'im al-Islam, İng. çeviri, giriş ve notlar: Gerard G. Salinger, 1953, s. viii, s. 411-432.

121 Bonner, age., s. 126-127; Hadduri, age., s. 76-77.

122 John Kelsay, "Al-Shaybani”, s. 69; Hadduri, age., s. 85-88.

123 İbn Ebî Şeybe, age., C VII, s. 605. 


\section{Olarak Savaş İdaresi}

O halde Sünnî âlimlerin cemaat hassasiyeti -ki onlardan ehl-i sünnet ve'l-cemâ'at olarak da bahsedilir- ve fitne korkusu, şiddet araçları üzerinde devlet tekeli oluşturmalarıyla sonuçlandı. Kur'ân'da tıpkı cihat gibi bireysel bir sorumluluk olarak tanımlanan, ama sonradan devlet mesuliyetine dönüştürülen iyiliği emretme ve kötülüğ̈̈ yasaklama (emr bi'l-ma'rûf ve nehy 'ani'l-münker) görevinin de farz-ı kifâye olarak gösterilmesi tesadüf değildi. Her iki görevin de devletten ya da imamdan bağımsız, bireysel olarak ifa edilebileceği görüşü zayıf kaldı. Çünkü cihat kesin olarak, iyiliği emretme ve kötülüğü yasaklama ise duruma göre şiddet araçlarını kullanmayı gerekli kılıyordu. Sünnî ulemâ cihatta görevin icrasını -eğer İslam toprakları topyekûn bir saldırı altında değilse- orduyla, emr bi'l-ma'rûfta ise -sözlü uyarı yetersiz kalıyorsa- muhtesibler ile sinırlandırarak her iki dinsel görevi de devletin ihtiyaç ve beklentilerine uygun hale getirmiş oldular.

Sünnî ulemânın cihat doktrinini revize ederken göz önünde bulundurmak zorunda kaldığı başka bir siyasi gerçeklik daha vardı. Arap yayılmacılığının çok hızlı olduğu zamanlarda klasik cihat düşüncesi çok etkili ve faydalıydı. Ancak birkaç nedenden dolayı bu düşüncenin öneminde bir azalma oldu. Öncelikle erken İslam fetihlerinde genel seferberlik gibi bir durum varken zamanla herkesin orduya alınmasının mümkün olmadığı bir evreye geçildi. Hem artık devletin yeterli sayıda askeri vardı hem de toplumun bir kesiminin askerî masrafları karşılamak için gerekli paranın çıkarılacağı kaynaklardan biri olarak askerlik mesleğinin dışında bırakılması gerekiyordu. Öte yandan uzak coğrafyaları fethetmek zor ve masraflı bir işti. Ganimet de eskisi kadar teşvik edici bir saldırı sebebi değildi; çünkü Bizans İmparatorluğu'nun uzak ve savaşla tahrip olmuş sınır bölgeleri sefer masraflarını karşılamıyordu ${ }^{124}$. Muhtemelen bu şartlar altında, yani devletin savaş ülküsüne sıkı sıkıya bağlı kalmasını gerektiren şartlar ortadan kalkınca İslam hukukçuları cihadı ferdî bir dinî sorumluluk olmaktan çıkarıp kimin savaşıp kimin savaşmayacağına devletin karar verdiği bir teşebbüse dönüştürdüler ve cihat ödevini bir farz-ı kifâye olarak bireyden cemaate (yani orduya) aktardılar ${ }^{125}$. Bu yeni durum Müslümanlara evlerinde oturup Allah'a başka şekillerde de ibadet etme ya da başka şekillerde de (dille, kalple veya elle) cihat yapma ruhsatı veriyordu. Şâfi'îfarz-ı kifâye doktrinini, Müslümanlardan bir kısmının dini iyice öğrenmek, dinî ilimlerle meşgul ol-

124 J. F. Haldon-H. Kennedy, "The Arab-Byzantine Frontier in the Eighth and Ninth Centuries: Military Organisation and Society in the Borderlands", Zbornik Radova 19 (Belgrade, 1980), s. 114-115; ayrica bk. Khalid Yahya Blankinship, The End of the Fihād State: The Reign of Hishām Ibn Abd Al-Malik and the Collapse of the Umayyads, State University of New York Press 1994, s. 117-118.

125 İbn Rüşd, age., s. 380-381; Hadduri, age., s. 69-70, 95; Noth, age., s. 41-43. 
mak ve kavimleri savaştan döndükten sonra onları dinî konularda ikaz edebilmek için evinde kalması gerektiği savıyla meşrulaştırdı ${ }^{126}$. O ayrıca eğer yeteri kadar savaşçı varsa savaşa katılmayanların günaha girmeyeceklerini şu Kur'ân ayetini (4:95) delil getirerek savundu: "Allah mallan ve canlaryla cihat edenleri derece bakumndan oturanlardan üstün kaldı. Gerçi Allah bütün müminlere o güzel geleceği vaat etmiştir ${ }^{127}$." Bazı hukukçular ise cihadı daimi bir mükellefiyet olarak gören doktrini, cihada hazırlanmanın cihat yükümlülüğünü yerine getirmek için yeterli olduğunu iddia ederek $^{128}$ yumuşattılar. Onların ve Şâfîînin yaptığı şey aslında var olan gerçekliği tanımaktan ibaretti.

\section{Sonuç}

Bütün bu verilerin ışı̆̆ında girişte ifade edilen ve literatürde epey yer tutan yaygin kanının aslında kaynaklarda pek de bir karşlığının olmadığı rahatlıkla söylenebilir. Buna göre, halifeler ile din âlimleri arasında cihat konusunda bir rekabet ya da ihtilaftan ziyade çeşitli şekillerde kendini gösteren bir iş birliğinden bahsetmenin daha gerçekçi olacağı görülmüştür. Bu bağlamda şu üç tespitin altını çizmek gerekiyor: Birincisi, din âlimleri arasında sınıra gidip savaşan isimler olsa da bu tercih bir akıma dönüşmedi. Zira din âlimleri arasında cihadın mecburi ve daimi bir savaş hali olduğunu sorgulayanların sayısı hiç de az değildi. Eğer öyle olmasaydı cihadın farz-ı kifâye olduğu şeklinde bir uzlaşmaya varılmazdı. Bu, basitçe dönemin siyasî gerçekliğinden kopuk bir fikhî düzenleme olarak görülmemeli. Fakihler zamanla katı prensiplere bağlı klasik cihat düşüncesi ile sürekli olarak değişen siyasî ve ekonomik gerçeklik arasındaki uçurumun farkına varmış ve bu yüzden cihat düşüncesini birçok kez gözden geçirme gereği hissetmişlerdi. Başka bir ifadeyle ulemâ, yöneticilerle aralarına koydukları mesafeye aldırmadan cihat üzerinden halifenin dinî otoritesini sorgulamak ya da aktif savaşçlar olarak ona rakip olmak şöyle dursun, cihat doktrinini değişen koşullara ve devletin ihtiyaç ve beklentilere göre şekillendirdi. İkinci tespit şudur ki, gönüllü din savaşçlarına atfedilen zühtçülük, hadisçilik ve halifeye muhalif olma özellikleri, kişiyi zorunlu olarak savaşçı olmaya götürmemekteydi. Her üç özelliğin de savaşçllıkla ve cihat ereğiyle güçlü bağları yoktu. Dönemin tipik bir zahit, hadisçi ya da halifeyi ve icraatlarını eleşti-

126 Şâfíî̀, age., C I, s. 168; Şâfíî, er-Risâle, Kâhire 1940, s. 365-366. Burada 9:122 ayeti delil getirilir ve bu ayetin Allah tarafindan cihada katılmayanların tehdit edildiği 9:39 ayetini neshettiği söylenir: bk. Ebû Dâvûd, age., C IV, s. 159.

127 Şâfîî, er-Risâle, s. 365.

128 Hadduri, age., s. 73. 


\section{Olarak Savaş İdaresi}

ren bir din âlimi, insanlarda muhtemelen bir savaşçı çağrışımı yapmıyordu ya da çok az örnekte yapıyordu. Son çıkarım ise zahit-savaşçların dinsel fazilet arayışlarının hilafetin ihtiyaç ve beklentileriyle çatışmadığı, mutatavvi ayı kendi liderlikleri altında toplayıp halifeye karşı örgütlemedikleri, hatta böyle bir niyetleri dahi olmadığıdır. Bildiğimiz tek şey, sayıları pek de fazla olmayan bu zahit-savaşçıların bir dönem ya da ara ara gazaya çıktıklarıdır. Üstelik gönüllü birliklerin düzenli ordularla birlikte savaşmalarının çok rutin bir uygulama olduğu görülmüştür.

\section{KAYNAKLAR}

Abdullâh b. el-Mübârek, Kitâbu'l-Cihâd, Dârü'l-Matbû‘âti'l-Hadîse, Cidde ty. Abdullâh b. el-Mübârek, Kitâbu'z-Zühd ve Yelîhi Kitâbu'r-Rekầik, Dârü'l-Kütübi'l-'Ilmiyye, Beyrut bt. yok.

Anonim, el-'Uyûn ve'l-Hadầik fì Ahbâri'l-Hakầik, Brill, Leiden 1871.

Armstrong, Lyall R., The Qussāas of Early Islam, Brill, Leiden 2017.

Belâzürî, el-Büldân ve Fütûhuhâ ve Ahkâmuhâ, Dârü'l-Fikr, Beyrut 1992.

Belâzürî, Kitâbu Cümel min Ensâbi’l-Eşrâf, Dârü'l-Fikr, Beyrut 1996.

Bonner, Michael, Fihad in Islamic History, Princeton University Press, 2006.

Buhârî, es-Sahîh, Dârü'l-Hüdâ, Cezayir 1992.

Chabbi, J., "Ribātẹ", Encyclopaedia of Islam, C VIII. Second Edition.

Cook, David, Understanding Fihad, University of California Press, 2005.

Crone, Patricia, "The first-century concept of hiğra", Arabica, 41 (1994).

Ebû Dâvûd, es-Sïnen, Dârü’r-Risaleti’l-'Âlemiyye, Dımaşk 2009.

Ebû İshâk el-Fezârî, Kitâbu’s-Siyer, Müessesetü'l-Risâle, Beyrut 1987.

Ebû Tâlib el-Mekkî, Kûtü'l-Kulûb fì Mu'âmeleti'l-Mahbûb ve Vasfu Tarîki'l-Mürîd ilâ Makâmi't-Tevhîd, Dârü'l-Kütübi'l-'İlmiyye, Beyrut 2005.

Ebû 'Ubeyd, Kitâbu'l-Emvâl, Dârü'l-Hedyi'n-Nebevî, Mansura 2007.

Ebû Yusûf, er-Red 'alâ Siyeri'l-Evzấ', Lecnetü İhyâ'i'l-Ma'ârifi'l-Nu'maniyye, Haydarâbâd Dekken bt. yok.

Ebû Yûsuf, Kitâbu'l-Harâc, el-Mektebetü'l-Ezheriyye li’t-Türâs, Kahire 1999. 
Ezdî, Târîhu'l-Mavsll, Dârü'l-Kütübi'l-‘ỉmiyye, Beyrut 2006.

Ezrakî, Ahbâru Mekke ve mâ Câe fîhâ mine’l-Âsâr, Mektebetü'l-Esedî, by. yok 2003.

Hadduri, Macid, İslam Hukukunda Savaş ve Barış, çev. Fethi Gedikli, Yöneliş Yay., İstanbul 1999.

Herevî, Kitâbu İsfari’l-Fasîh, İmadetü'l-Bahsi'l-'İlmî, Medine 1420.

İbn Ebî Şeybe, el-Musannef fì'l-Ehâdis ve'l-Âsâr, Dârü'l-Fikr, Beyrut 1989.

İbn Ebî Ya‘la, Tabakâtül'-Hanâbile, Dârü'Kütübi'l-'İlmiyye, Beyrut 1997.

İbn Ebî'd-Dünya, Kitâbu'l-Emr bi'l-Ma'rûf ve Nehy 'ani'l-Münker, Medinetü'n-Nebeviyye 1997.

İbn Hacer el-'Askalânî, Ref'u'l-Isr 'an Kudâti Musr, Kahire 1988.

İbn Havkal, Kitâbu Sûreti'l-Ád, Dâru Sadır, Beyrut bt. yok.

İbn Hazm, el-Muhallâ, İdâretü’t-Tıbâ‘ati'l-Münîriyye, Kahire 1349.

İbn Kuteybe, Kitâbu 'Uyûni'l-Ahbâr, Dârü'l-Kitâbi'l-'Arabî, Beyrut 2002.

İbn Kuteybe, el-İmâme ve's-Siyâse, Dârü'l-Kütübi'l-'İlmiyye, Beyrut 2006.

İbn Manzûr, Lisânü'l-'Arab, Dârü Sâdır, Beyrut 2010.

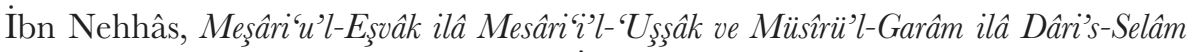
(fi'l-Cihâad ve Fezẩilihi), Dârü'l-Beşâ’iri'l-İslâmiyye, Beyrut 1990.

İbn Rüşd, Bidâyetü'l-Müctehid ve Nihâyetü'l-Muktesıd, Mektebetü ve Matba'atü Mustafa el-Bâbî el-Halebî, Kahire 1975.

İbn Sa'd, Tabakâtü’-Kübrâ, Dârü'l-Kütübi'l-'İlmiyye, Beyrut, 1997.

İbn Şebbe, Târîhu'l-Medîneti'l-Münevvere, Cidde 1399.

İbnü'l-Gevzî, el-Muntazam fì Târîhi'l-Ümem ve'l-Mülûk, Dârü'l-Kütübi'l-'İlmiyye, Beyrut 1992.

İbnü'l-Cevzî, Srfâtü's-Safve, Dârü'l-Hadîs, Kahire 2000.

İbnü'l-Esîr, el-Kâmil fi't-Târîh, Beytü'l-Efkâri'd-Düveliyye, by. ve bt. yok.

İbnü'l-Mülakkın, et-Tavzîh li-Şerhi'l-Câmi' 'i’s-Sahîh, Dârü'n-Nevâdir, Dımaşk 2008.

İsbehânî, Hilyetii'l-Evliyâ' ve Tabakâtü'l-Esfiyâa', Dârü'l-Hadîs, Kahire 2009.

Kazvînî, Âsâru'l-Bilâd ve Ahbâru'l-'íbâd, Dârü Sâdır, Beyrut bt. yok. 
Olarak Savaş İdaresi

Kelâbâzî, Kitâbu't-Ta'arruf li Mezhebi ehli't-Tasavvuf, Mektebetü'l-Hâncî, Kahire 1994.

Kelsay, John, "Al-Shaybani and the Islamic Law of War", fournal of Military Ethics, II/ 1 (2003).

Kelsay,John, "Comparison and History in the Study of Religious Ethics: An Essay on Michael Cook's Commanding Right and Forbidding Wrong in Islamic Thought", Journal of Religious Ethics, 35/2 (2007).

Kindî, Kitâbu'l-Vulât ve Kitâbu’l-Kudât, Dârü’l-Kütübi'l-'İlmiyye, Beyrut 2003.

Kudâme b. Ca'fer, Kitâbu'l-Harâc ve Sinâ‘atü’l-Kitâbe, Dârü’r-Reşîd lî’n-Neşr, 1981.

Makdisî, Kitâbu'l-Bed' ve't-Târîh, Mektebetü's-Sekâfeti'd-Dîniyye, by. ve bt. yok.

Mâlik b. Enes, el-Muvattâ, Dâru İhyâi Türâsi'l-'Arabî, Beyrut 1985.

Maverdî, Kitâbu'l-Ahkâmi's-Sultâniyye, Dârü'l-Fikr, Beyrut bt. yok.

Mes'ûdî, Mürûcu'z-Zeheb, Dârü İhyâi't-Türâsi'l-'Arabî, Beyrut bt. yok.

Muhammed, Nizâr Azîz Habîb, "Kâdı'l-Cünd", Mecelletü Ebhâsi'l-Basra, XXXVIII/1 (2013).

Muhâsibî, Âdâbu'n-Nufûs yelihi Kitâbu't-Tevehhüm, Müessesetü'l-Kütübi's-Sekâfiyye, Beyrut 1991.

Neale, Harry S., Fihad in Premodern Sufi Writings, Palgrave Macmillan, New York 2017.

Nesâî, Kitâbu’s-Süneni'l-Kübrâ, Dârü'l-Kütübi’l-'Illmiyye, Beyrut 1991.

Noth, Albrecht, Müslümanlıkta ve Hiristiyanlıkta Kutsal Savaş ve Mücadele, çev. İhsan Çatay, Özne Yay., İstanbul 1999.

Sahner, Christian C., "The Monasticism of My Community is Jihad: A Debate on Asceticism, Sex and Warfare in Early Islam", Arabica, LXIV/2 (2017).

San‘ânî, el-Musannef, el-Meclisü'l-'İlmî, Beyrut 1972.

Sem‘ânî, el-Ensâb, Meclisü Dâ'ireti’l-Me‘ârifi'l-'Osmâniyye, Haydarâbâd 1977.

Sülemî, Tabakâtü’s-Sûfıyye, Dârü'l-Kütübi'l-'İlmiyye, Beyrut 1998.

Şâfîî, er-Risâle, Mektebetü'l-Halebî, Kâhire 1940. 
Şâfîî, el-Ümm, Dârü'l-Vefâ, 2001.

Şeybânî ve Serahsî, Şerhu Kitâbi's-Siyeri'l-Kebîr, Dârü'l-Kütübi'l-'İlmiyye, Beyrut 1997.

Taberî, Târih (Târîhu'l-Ümem ve'l-Mülûk), Beytü'l-Efkâri'd-Düveliyye, by. ve bt. yok.

Taberî, Kitâbu'l-Cihâd ve Kitâbu'l-Cizye ve Ahkâmu'l-Muhâribîn min Kitâbi İtiliấfi'l-Fukâhâ, Leiden 1933.

Tirmizî, el-Menhiyyât, Mektebetü'l-Kur'ân, Kahire 2002.

Tor, Deborah G., Violent Order: Religious Warfare, Chivalry, and the Ayyar Phenomenon in the Medieval Islamic World, Istanbuler Texte und Studien der Deutschen Morgenländischen Gesellschaft, Ergon Verlag, Würzburg 2007.

Zehebî, Târîhu'l-İslâm ve Vefayâtii'l-Meşâhir ve'l-A 'âm, Dârü'l-Garbi'l-İslâmî, Beyrut 2003.

Zehebî, Siyerï A'lâmi’n-Nïbelâ, Beytü’l-Efkâri’d-Düveliyye, Lübnan 2004. 